\title{
Regioselective synthesis of pyrimido[1,2-a][1,3,5]triazin-6-ones via reaction of 1 - (6-oxo-1,6-dihydropyrimidin-2-yl)guanidines with triethylorthoacetate: observation of an unexpected rearrangement
}

\author{
Nikhil Sachdeva ${ }^{\mathrm{a}}$, Anton V. Dolzhenko ${ }^{\mathrm{b}}$ and Wai Keung Chui ${ }^{\mathrm{a}}$ \\ ${ }^{a}$ Department of Pharmacy, Faculty of Science, National University of Singapore, 18 Science Drive 4, Singapore \\ 117543, Singapore.E-mail: phacwk@nus.edu.sg,nicks.sachdeva81@gmail.com; Tel: +65 6516 2933; Fax: +65 \\ 67791554 \\ ${ }^{b}$ School of Pharmacy, Curtin Health Innovation Research Institute, Curtin University of Technology, GPO Box \\ 1987, Perth, Western Australia 6845, Australia
}

Graphical Abstract



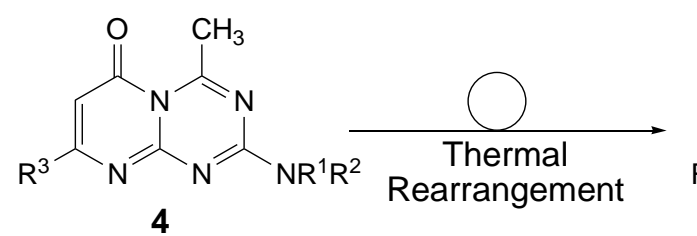

4

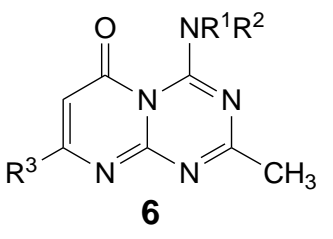

6

\begin{abstract}
A novel thermal rearrangement, involving pyrimidine ring opening and subsequent ring closure leading to recyclization of the system, was identified in the reaction of (6-oxo-1,6dihydropyrimidin-2-yl)guanidines 3 (where $\mathrm{NR}^{1} \mathrm{R}^{2}=\mathrm{NH}_{2}, \mathrm{NH}$ alkyl, $\mathrm{NH}$ aralkyl, $\mathrm{NHCH}_{2} \mathrm{Ph}(\mathrm{R})$ ) with triethyl orthoacetate, affording 4-substituted-2-methyl-6H-pyrimido[1,2-a][1,3,5]triazin-6ones 6 and their ring opened products. However, no such rearrangement was observed with (6oxo-1,6-dihydropyrimidin-2-yl)guanidines $\mathbf{3}$ bearing a tertiary amino or anilino substituent (i.e. where $\mathrm{NR}^{1} \mathrm{R}^{2}=\mathrm{N}\left(\mathrm{CH}_{3}\right)_{2}$, indoline, morpholino, NHAr). As expected, 2-substituted-4-methyl$6 H$-pyrimido[1,2-a][1,3,5]triazin-6-ones 4 were obtained as the final products. Experimental
\end{abstract}


structural determination and theoretical studies were carried out to get an understanding of the observed thermal rearrangement. In addition, an attempt to obtain similar pyrimido[1,2a][1,3,5]triazin-6-ones using $N, N$-dimethylacetamide dimethyl acetal (DMA-DMA) as one carbon inserting synthon had furnished triazine ring annulated product $\mathbf{1 4}$ bearing N,N-dimethyl enamino substituent at position 4 as a result of further reaction with a second molecule of DMADMA.

Keywords: pyrimidines, triazines, guanidines, pyrimido[1,2- $a][1,3,5]$ triazines, X-ray crystal structure, rearrangement

\section{Introduction}

1,3,5-triazine nucleus is a prominent structural core present in numerous biologically active compounds. Hexamethylmelamine, irsogladine and 5-aza-2'-deoxycytidine, which are structurally based on the 1,3,5-triazine scaffold, have been found to exhibit anti-cancer and antiangiogenic properties $^{1}$. Various 1,3,5-triazine derivatives fused to quinazoline ${ }^{2}$, benzimidazole ${ }^{3}$, pyrazole ${ }^{4,5}$ and 1,2,4-triazine ${ }^{6}$ have been reported to show anti-cancer properties. Moreover, numerous derivatives of pyrimidine fused systems such as pyrido[2,3- $d]$ pyrimidine $(\mathrm{PD}-0332991)^{7}$ and pyrimido[1,2-a]pyrimidine $(\mathbf{4})^{8}$ have also demonstrated promising anticancer properties as well. Due to the close structural similarity with the above pyrimido fused bicyclic scaffolds and reports on antiproliferative activity from 1,3,5-triazino fused heterocycles, the derivatives of pyrimido[1,2-a][1,3,5]triazine scaffold were anticipated to possess anticancer property (Fig. 1). To date, heterocyclic compounds possessing a pyrimido[1,2-a][1,3,5]triazine moiety have been reported to exhibit antimicrobial ${ }^{9}$, potent fungicidal and average serotoninergic 
(5-HT $\mathrm{HA}_{1 \mathrm{~A}}$ and $5-\mathrm{HT}_{1 \mathrm{~B}}$ receptor) activities ${ }^{10}$ as well as GSK-3 $\beta$ inhibitory activity with potential for the treatment of neurodegenerative diseases ${ }^{11}$<smiles>COc1ccc(CCN2c3nc(N4CCOCC4)cc(=O)n3CCC2C(F)(F)F)cc1</smiles>

pyrimido[1,2-a]pyrimidine

$\mathrm{IC}_{50}(\mathrm{PC} 3)$ value $=11 \mathrm{nM}$<smiles>CC(=O)c1c(C)c2cnc(Nc3ccc(N4CCNCC4)cn3)nc2n(C2CCCC2)c1=O</smiles>

Pyrido[2,3-d]pyrimidinones

CDK4 + CDK6 inhibitor-PD-0332991<smiles>Cn1c(=O)nc2[nH]ncnc-2c1=O</smiles>

pyrimido[4,5-e][1,2,4]triazine

Antitumour antibiotic-Reumycin

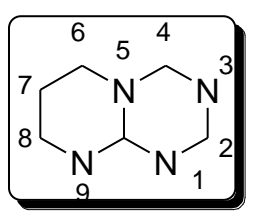

pyrimido[1,2-a][1,3,5]triazine<smiles>CC1(C)CC(=O)C2=C(C1)NC(=S)N[C@H]2c1cccc(O)c1</smiles>

benzo[d]pyrimidine human kinesin Eg5 inhibitor-Dimethylenastron<smiles>N#Cc1cnn2c(Nc3ccccc3)nc(Nc3ccccc3)nc12</smiles>

pyrazolo[1,5-a] [1,3,5]triazine $\mathrm{IC}_{50}(\mathrm{HCT} 116)$ value $=0.99 \mu \mathrm{M}$<smiles>NC1=NC2=Nc3ccccc3CN2C(c2ccc(Br)cc2)N1</smiles>

1,3,5-triazino[2,1-b]quinazolines

$\mathrm{GI}_{50}(\mathrm{~A} 549)$ value $=15 \mu \mathrm{M}$

Fig. 1 Structurally similar nitrogen containing heterocyclic scaffolds

In the literature, synthetic access to pyrimido[1,2-a][1,3,5]triazine analogues (in which one of the four nitrogen atoms is located at the junction of the two cycles) is rather limited and most of the synthetic approaches described cannot provide the flexibility of different substitution at various

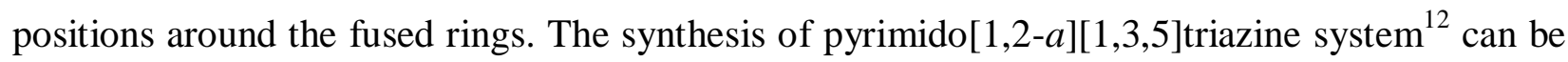
categorized into two approaches: (1) annulation of pyrimidine onto a 1,3,5-triazine scaffold ${ }^{13} ;(2)$ annulation of the 1,3,5-triazine ring onto a pyrimidine scaffold ${ }^{14}$. The latter approach has been 
largely adopted for the preparation of pyrimido[1,2-a][1,3,5]triazines and most authors largely focussed on the formation of dioxo/dithio/oxothiooxo derivatives of the scaffold ${ }^{14 \mathrm{~g}-\mathrm{p}}$. Therefore, there is a need to find more practical approaches for the synthesis of these pyrimido[1,2a][1,3,5]triazines.

Since orthoesters are versatile one-carbon building blocks in ring annulation reactions, it was expected that unsymmetrically substituted pyrimidin-2-yl guanidine $\mathbf{3}$ (acting as a penta atomic synthon) would react with this one-carbon building block to yield, theoretically, either one of the regioisomeric pyrimido[1,2-a][1,3,5]triazin-6-ones $\mathbf{4}$ or $\mathbf{5}$ or both as product/s. However, the possibility of structure $\mathbf{5}$ was excluded, as no cross-peaks were found between the $\mathrm{R}^{3}$ group protons of pyrimidine ring and methyl group protons of triazine ring in 2D NOESY experiment (Scheme 1). Moreover, according to DFT calculations in gas phase, the structure 5 was found to be highly unfavourable energetically (vide infra). In addition, a regioisomeric product similar to 4 was observed exclusively when other one-carbon inserting synthon like aldehyde was used with similar substrate ${ }^{15}$. However, to our surprise, product 4 (Table 1) was found readily rearranged insitu to a thermodynamically more favourable product of type $\mathbf{6}$ and its ring-opened product 6 ' (Scheme 3), depending upon the $\mathrm{NR}^{1} \mathrm{R}^{2}$ group present in the starting material guanidine (Table 2). Herein, the details of this unexpected thermal rearrangement are presented.

\section{Results and Discussion}

The starting material $N$-(4-substituted-6-oxo-1,6-dihydropyrimidin-2-yl)guanidines, $\mathbf{3}$, were prepared either by method A or B (Scheme 1). In method A, 3 was synthesized via microwave (MW) assisted nucleophilic addition of amines onto (4-methyl-6-oxo-1,6-dihydropyrimidin-2yl)cyanamide 1 using either concentrated hydrochloric acid or trimethyl silyl chloride (TMSCl) 
catalyzed conditions; whereas in method $\mathrm{B}$, cyclocondensation of $\beta$-keto ester with substituted biguanides 2 yielded 3 as reported by Curd and $\operatorname{Rose}^{16}$ (Scheme 1). Method A was found to be more versatile and robust for molecular library generation. In the presence of protic acid (method A procedure 1) or TMSCl (method A procedure 2) catalyzed conditions, the reaction times were shorter, workup was easy obviating the need of column chromatography and appreciable yields of $3(56-93 \%)$ were obtained with a variety of primary and secondary amines with alkyl, aryl and aralkyl substituents. In the latter case (i.e. method A procedure 2), TMSCl not only acted as a source of anhydrous $\mathrm{HCl}$, but it also activated cyanamide $\mathbf{1}$ as shown in scheme 2.

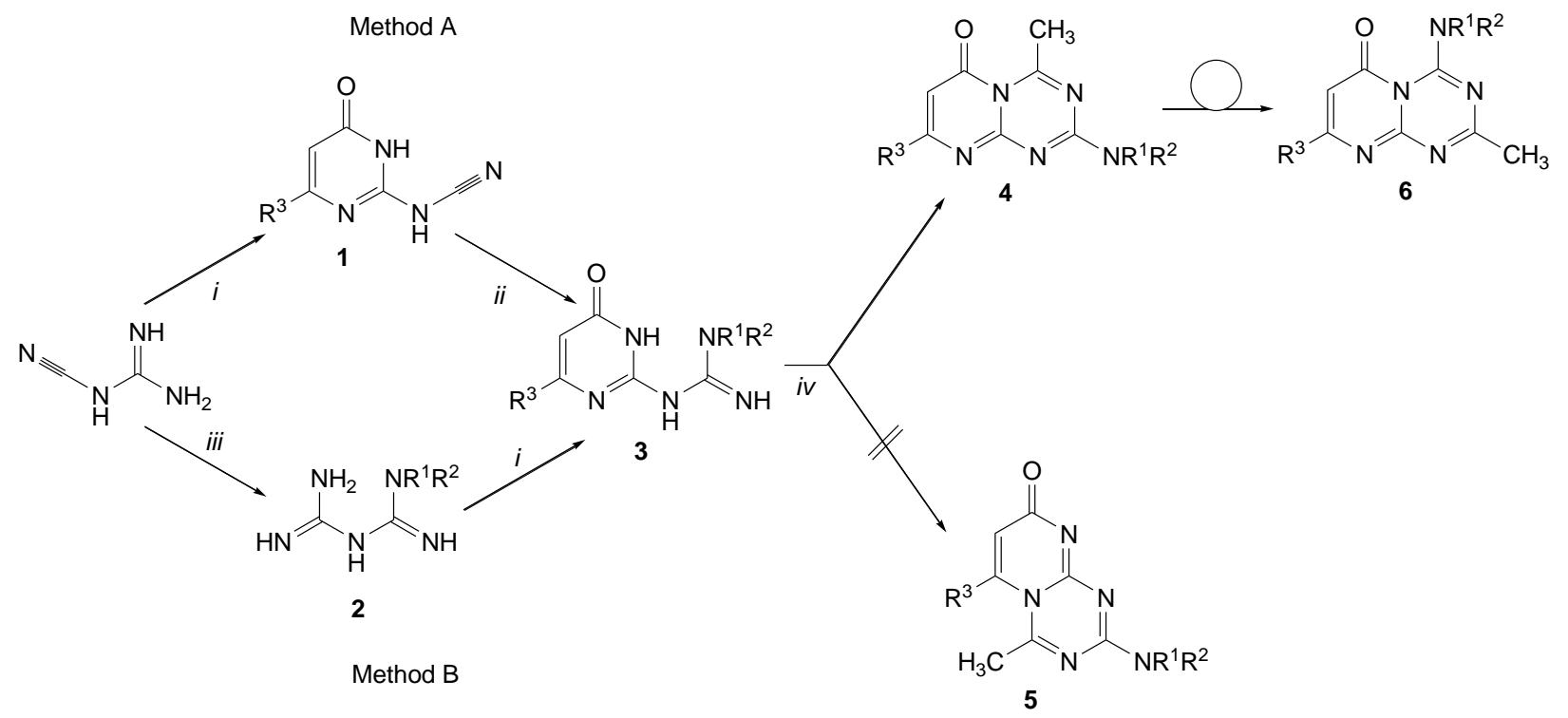

Scheme 1. Reagents and Conditions: (i) ethyl 3-oxobutanoate/ ethyl 4,4,4-trifluoro-3oxobutanoate, aq. $\mathrm{NaOH}$, r.t., $12 \mathrm{~h}(77 \%)$; (ii) procedure $1 \mathrm{HNR}^{1} \mathrm{R}^{2} \cdot \mathrm{HCl}, \mathrm{MW}, 160^{\circ} \mathrm{C}, 15 \mathrm{~min}$ or procedure $2 \mathrm{NR}^{1} \mathrm{R}^{2}$, TMSCl, $\mathrm{CH}_{3} \mathrm{CN}, 12$ min., $160^{\circ} \mathrm{C}$ followed by $i \mathrm{PrOH}, 125^{\circ} \mathrm{C}, 30 \mathrm{sec}$. $(62 \%$ 79\%); (iii) $\mathrm{HNR}^{1} \mathrm{R}^{2} . \mathrm{HCl}, \mathrm{C}_{4} \mathrm{H}_{9} \mathrm{OH}$, reflux, 6h (40\%); (iv) $\mathrm{CH}_{3} \mathrm{C}(\mathrm{OEt})_{3}$, AcOH, reflux, 3-9h 
Table 1 Structures and yields of intermediates and isolated pyrimido[1,2-a][1,3,5]triazin-6-one products

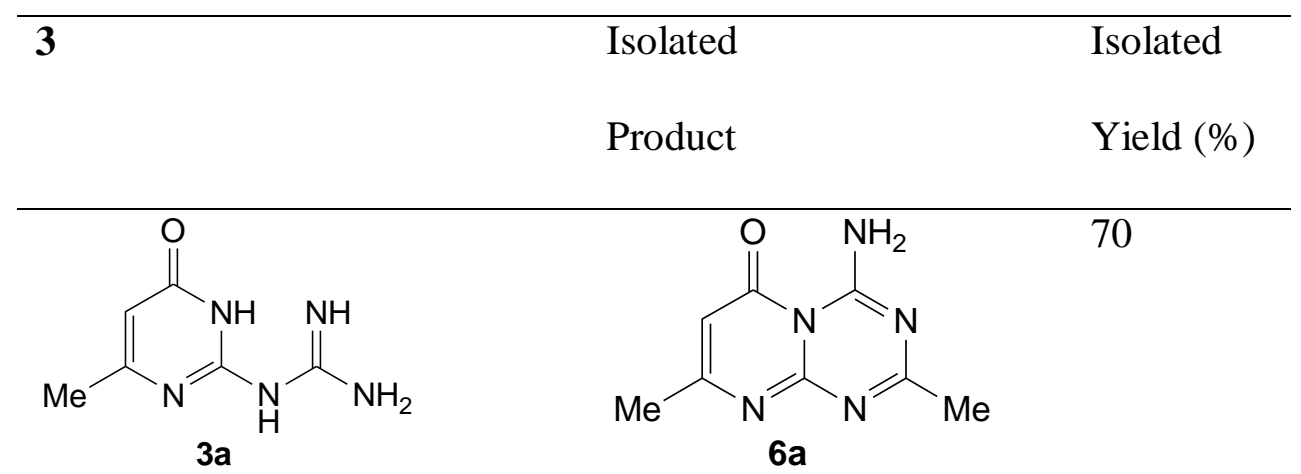<smiles>N=C(N)Nc1nc(-c2ccccc2)cc(=O)[nH]1</smiles><smiles>Cc1nc(N)n2c(=O)cc(-c3ccccc3)nc2n1</smiles><smiles>COc1cc(=O)[nH]c(NC(=N)N(C)C)n1</smiles><smiles>CNc1nc(C)nc2nc(C)cc(=O)n12</smiles><smiles>Cc1cc(=O)[nH]c(NC(=N)Nc2ccccc2)n1</smiles><smiles>Cc1cc(=O)n2c(C)nc(Nc3ccccc3)nc2n1</smiles><smiles>Cc1cc(=O)[nH]c(NC(=N)Nc2cccc(Cl)c2)n1</smiles><smiles>Cc1cc(=O)n2c(C)nc(Nc3cccc(Cl)c3)nc2n1</smiles> 
<smiles>COc1ccc(NC(=N)Nc2nc(C)cc(=O)[nH]2)cc1</smiles><smiles>Cc1cc(=O)[nH]c(NC(=N)NCc2ccccc2)n1</smiles><smiles>COc1ccccc1CNC(=N)Nc1nc(C)cc(=O)[nH]1</smiles><smiles>Cc1cc(=O)[nH]c(NC(=N)N(C)C)n1</smiles>

$3 \mathbf{i}$<smiles>Cc1cc(=O)[nH]c(NC(=N)N2CCOCC2)n1</smiles><smiles>COc1ccc(Nc2nc(C)n3c(=O)cc(C)nc3n2)cc1</smiles><smiles>Cc1cc(=O)n2c(NC[Pb](Cl)(Cl)Cl)nc(C)nc2n1</smiles><smiles>CO[14CH2]CNc1nc(C)nc2nc(C)cc(=O)n12</smiles><smiles>Cc1cc(=O)n2c(C)nc(N(C)C)nc2n1</smiles><smiles>Cc1cc(=O)n2c(C)nc(N3CCOCC3)nc2n1</smiles> 
<smiles>Cc1cc(=O)[nH]c(NC(=N)N2CCc3ccccc32)n1</smiles><smiles>Cc1cc(=O)n2c(C)nc(N3CCc4ccccc43)nc2n1</smiles><smiles>N=C(Nc1cccc(Br)c1)Nc1nc(C(F)(F)F)cc(=O)[nH]1</smiles><smiles>Cc1nc(Nc2cccc(Br)c2)nc2nc(C(F)(F)F)cc(=O)n12</smiles>

Solvents used for crystallisation: ${ }^{\mathrm{a}} \mathrm{EA},{ }^{\mathrm{b}} 80 \mathrm{EA}: 20 \mathrm{Hex},{ }^{\mathrm{c}} 90 \mathrm{EA}: 10 \mathrm{MeOH} ;{ }^{\mathrm{d}} \mathrm{EtO} H$<smiles>[R]c1cc(=O)[nH]c(NCN)n1</smiles>

1

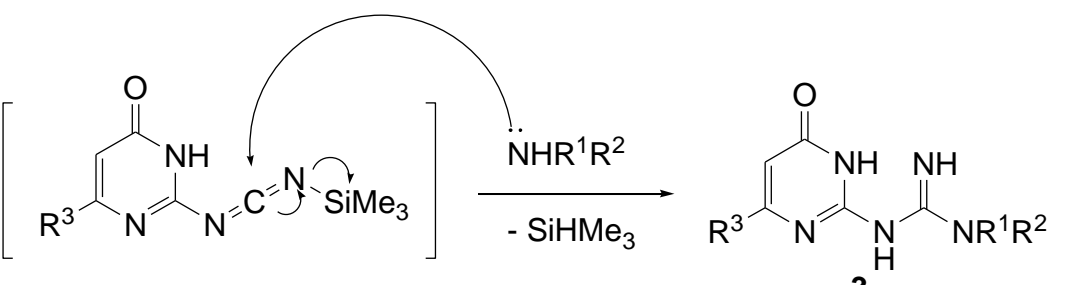

3

Scheme 2. Synthesis of 1,6 dihydropyrimidinyl guanidines 3 under TMSCl catalyzed conditions

The structures of the products were deduced from their mass spectra, NMR data and elemental analyses. The reactions were carefully monitored using TLC and the reactions were stopped immediately when no trace of the starting material was observed. The reaction proceeded only on heating at $100^{\circ} \mathrm{C}$. The reaction between these guanidines (3) and triethyl orthoacetate (in presence of glacial acetic acid) yielded product $\mathbf{4}$ predominantly when the guanidine $\mathbf{3}$ contained a tertiary amino group (3i-k) $\left(\mathrm{NR}^{1} \mathrm{R}^{2}=\mathrm{N}\left(\mathrm{CH}_{3}\right)_{2},-\mathrm{N}\left(\mathrm{CH}_{2} \mathrm{CH}_{2}\right)_{2} \mathrm{O}\right.$, indolino). Similarly when an aryl secondary amino group was included as in $\mathbf{3 d}, \mathbf{3 e}, \mathbf{3 f}$ and $\mathbf{3 l}\left(\mathrm{NR}^{1} \mathrm{R}^{2}=\mathrm{NHPh}, \mathrm{NHPh}(3-\mathrm{Br})\right.$, $\mathrm{NHPh}(3-\mathrm{Cl}), \mathrm{NHPh}(4-\mathrm{OMe}))$, the predominant compound was 4 . Product 4 was characterized by 
the diagnostic methyl peak of the triazine ring at $82.85-2.91$ in ${ }^{1} \mathrm{H}$ NMR and $26.2-27.8$ in ${ }^{13} \mathrm{C}$ NMR as well as X-ray crystallography of 4i (Fig. 2; please refer to supporting information for structural details). However, upfield shift to $82.18-2.29$ in ${ }^{1} \mathrm{H}$ NMR and 25.2-25.6 in ${ }^{13} \mathrm{C}$ NMR were observed, surprisingly, in isolated products when unsubstituted (3a), alkylsubstituted (3b) or aralkyl guanidines $(\mathbf{3 g}, \mathbf{3 h})$ were used as a substrate under similar conditions. Therefore, the product obtained from reactants $\mathbf{3 a}, \mathbf{3 b}, \mathbf{3 c}, \mathbf{3 g}$ and $\mathbf{3 h}$ was expected to have a structure different from 4 even though the mass spectra showed expected values corresponding to structure 4 . Hence, to confirm this aspect, X-ray crystallographic study of the product obtained from 3a was performed.

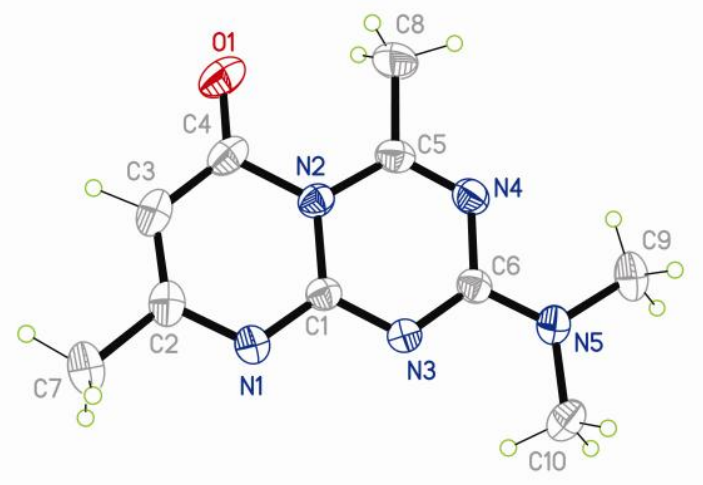

Figure 2. X-ray crystal structure of 2-(dimethylamino)-4,8-dimethyl-6H-pyrimido[1,2a][1,3,5]triazin-6-one 4i (displacement ellipsoids are drawn at 50\% probability level) CCDC 791289

The fact that there were clearly differentiated chemical shifts at $\delta 10.18$ and 9.26 for the product obtained by the reaction of triethyl orthoacetate with $\mathbf{3 a}$ in the ${ }^{1} \mathrm{H}$ NMR spectrum supported the existence of hydrogen bonding between the peri-carbonyl and the proximate exocyclic $\mathrm{N}-\mathrm{H}$ which is not possible in structure 4. Moreover, similar lowfield shifts of NH proton in ${ }^{1} \mathrm{H}$ NMR from 10.18-13.20 ppm were observed in $\mathbf{6 b - c}$ and $\mathbf{6 g - h}$. X-ray crystallographic study ${ }^{17}$ of this 
product (Figure 3) revealed that the product $\mathbf{4 a}$ (not isolated) underwent a smooth rearrangement to an isomeric product $\mathbf{6 a}$ in-situ as suspected from NMR studies. So, structure $\mathbf{6}$ was assigned to the rearranged product with upfield shift, in the cases of $\mathbf{3 a}, \mathbf{3 b}, \mathbf{3 c}, \mathbf{3 g}$ and $\mathbf{3 h}$. Moreover, NMR studies were found to be consistent with the X-ray crystallographic data of $\mathbf{6 a}$ (Figure 3) where hydrogens attached to N5 have unequal bond lengths and the amino group was found to be locked in the plane of pyrimido[1,2-a][1,3,5]triazine nucleus due to the $\pi$-electron delocalization with the heterocycle.

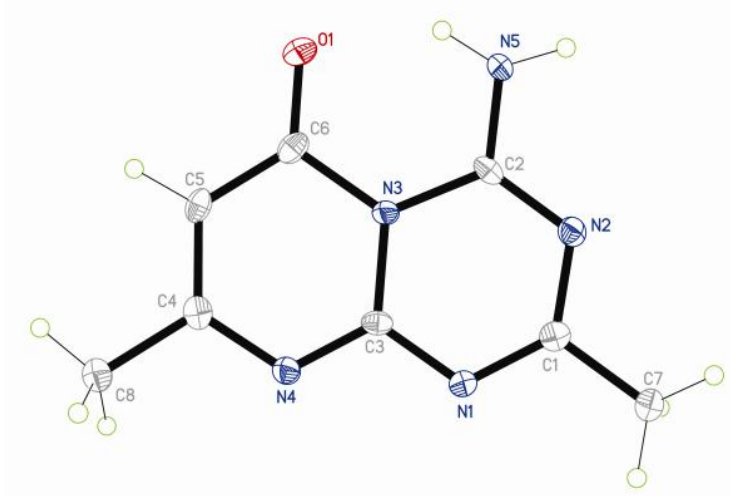

Figure 3. X-ray crystal structure of 4-amino-2,8-dimethyl-6H-pyrimido[1,2-a][1,3,5]triazin-6one 6a CCDC 788427

The proposed mechanism for the formation of rearranged product $\mathbf{6}$ is depicted in Scheme 3. The reaction starts with the exchange of alkoxy groups of the orthoester (in excess) under acid catalysis, which then reacted with the guanidine $\mathbf{3}$ (nucleophile) to give iminium ion intermediate 7. Subsequent loss of EtOH gave 4. Thermal rearrangement is then assumed to proceed at around $100^{\circ} \mathrm{C}$ for substrates $\mathbf{3 a}, \mathbf{3 b}, \mathbf{3 c}, \mathbf{3 f}$ and $\mathbf{3 g}$ (i.e. when either $\mathrm{R}^{1}$ or $\mathrm{R}^{2}=\mathrm{H}$ ) according to scheme 3 . The mechanism may have involved: a) acid catalyzed ethanolytic ring opening of pyrimidine at amide linkage with the formation of ring open triazine carbenone 6' (acrylic acids were isolated); b) intramolecular nucleophilic attack by N-1 nitrogen of 1,3,5-triazine on the carbonyl group and subsequent ring closure that gave final product $\mathbf{6}$. It is worth mentioning that the thermally 
assisted rearrangement of 4-amino-8-methylpyrimido[1,2-a][1,3,5]triazin-6-one 8 to 4-amino-6methylpyrimido[1,2-a][1,3,5]triazin-6-one $\mathbf{1 0}$ was $^{\text {reported }}{ }^{14 \mathrm{~b}}$ to have resulted from $1,3,5$ triazine ring opening via carbodiimide intermediate 9 (Scheme 4). However, the rearrangement involving pyrimidine ring opening similar to the one proposed in scheme 3 (depicted using hashed arrows in scheme 4) leading to product 12 via ketene intermediate 11 could not be avoided. Moreover, careful analysis of the provided ${ }^{1} \mathrm{H}$ NMR spectral data seems to corroborate structure 12 (2-amino-8-methylpyrimido[1,2- $a][1,3,5]$ triazin-6-one) as $\sim 1.2$ ppm downfield shift of the methine proton (in blue) signal on the triazine ring after the rearrangement can only be accounted to the deshielding effect of the neighboring carbonyl group in $\mathbf{1 2}$.

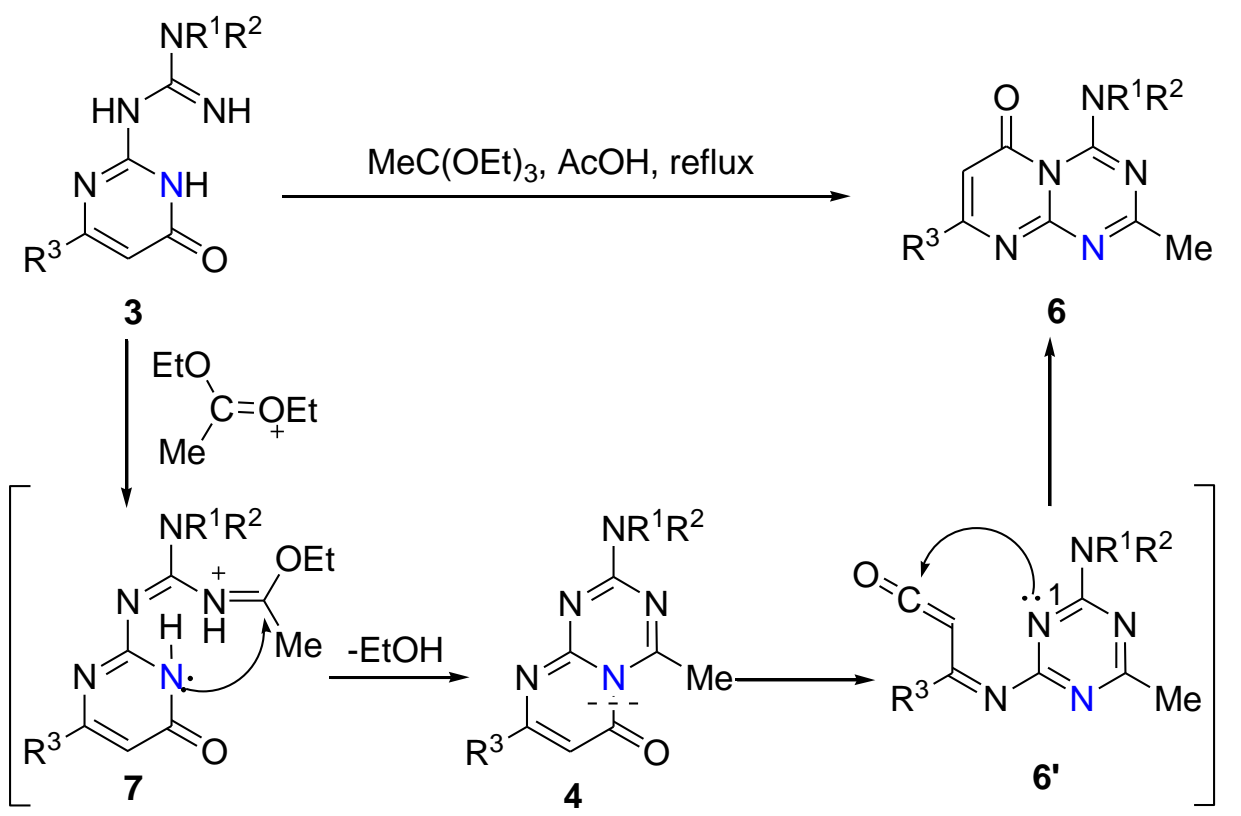

Scheme 3. Proposed mechanism for the formation of compound 6 


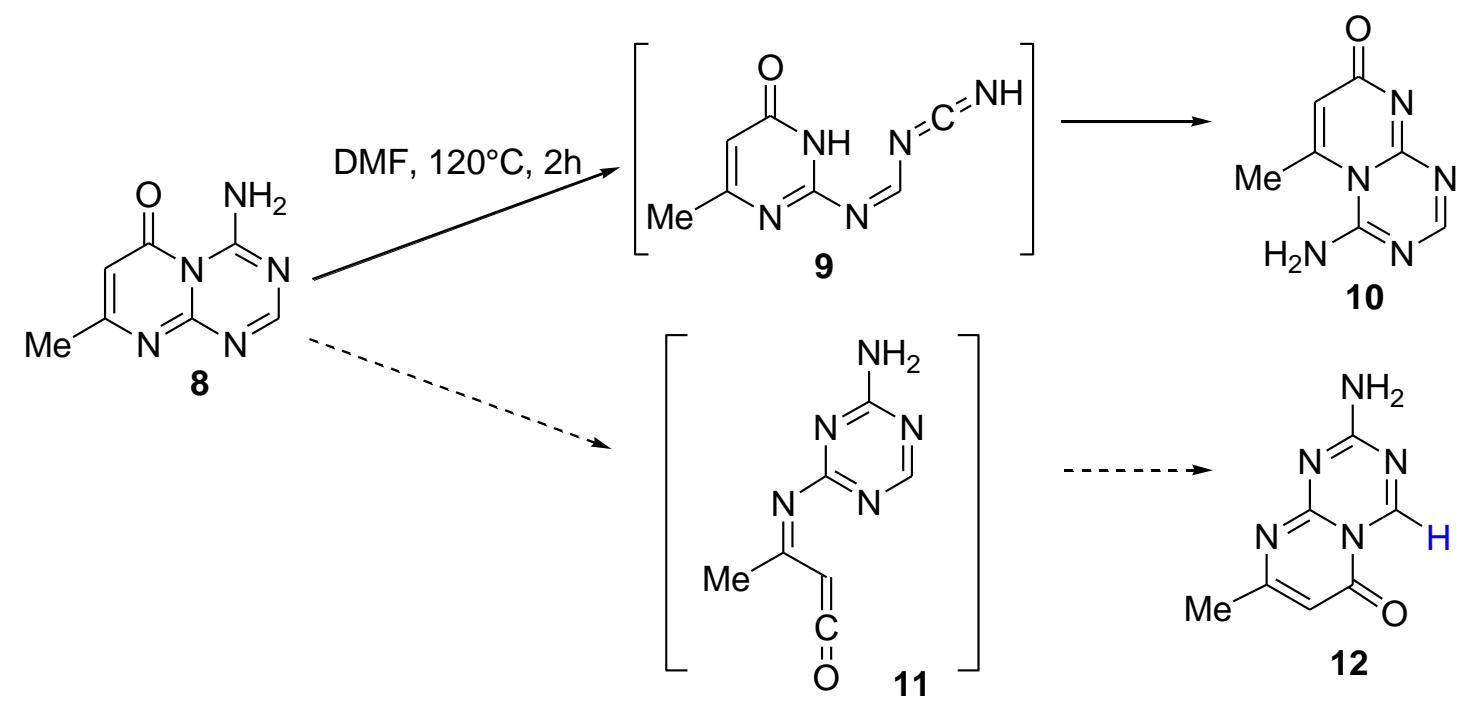

Scheme 4. Alternate plausible mechanism for the rearrangement in pyrimido[1,2a][1,3,5]triazin-6-ones via pyrimidine ring opening leading to regioisomeric product $\mathbf{1 2}$ instead of proposed $\mathbf{1 0 .}$

Intramolecular hydrogen bonding between the 4-amino hydrogen and carbonyl oxygen (Figure 3) as well as involvement of amino group (directly attached to the ring) in $\pi$-electron delocalization with the pyrimido[1,2-a][1,3,5]triazin-6-one nucleus provides additional stability to the rearranged product $\mathbf{6}$ which might provide the driving force for such a rearrangement. Therefore, an attempt was made to assess the relative stability of the two possible cyclocondensation products- 4 and $\mathbf{6}$ in gas phase for substitutions $\mathbf{a}\left(\mathrm{R}^{1}=\mathrm{R}^{2}=\mathrm{H}\right)$ and $\mathbf{i}$ $\left(\mathrm{R}^{1}=\mathrm{R}^{2}=\mathrm{Me}\right)$ using Gaussian 03 software package ${ }^{18}$. Regioisomer $\mathbf{5}$ was also included in the study as the similar cyclization of benzimidazol-2-yl guanidines (unsymmetrically substituted in the phenylene fragment) with one carbon inserting reagents did not proceed regioselectively in one of our previous works ${ }^{3}$. The results of these calculations are presented in Table 2. Rearranged product $\mathbf{6 a}$ was found to be energetically more favourable than $4 \mathbf{a}$ whereas $4 \mathbf{i}$ was found to be more favourable over 6i (Table 2). This was found to be in agreement with the 
experimental observation. Theoretical calculations at B3LYP/6-311G 2d,2p// B3LYP/6-311G $\mathrm{d}, \mathrm{p}$ explained the formation of exclusively one regioisomeric product as both $\mathbf{5 a}$ and $\mathbf{5 i}$ were highly energetically unfavourable (might be due to steric factors).

Table 2 Relative energies according to ab-initio calculations

\begin{tabular}{lccc}
\hline & \multicolumn{3}{c}{ Relative energies, $\mathrm{kcal} / \mathrm{mol}$} \\
\hline & $\mathbf{4}$ & $\mathbf{5}$ & $\mathbf{6}$ \\
\cline { 2 - 4 } $\mathbf{a} \mathbf{R}^{1}=\mathrm{R}^{2}=\mathrm{H}$ & 4.14 & 21.81 & 0.00 \\
$\mathbf{i} \mathbf{R}^{1}=\mathrm{R}^{2}=\mathrm{CH}_{3}$ & 0.00 & 17.65 & 8.72 \\
\hline
\end{tabular}

In an attempt to obtain similar pyrimido[1,2-a][1,3,5]triazin-6-ones, the reaction of 3i with another one carbon electrophilic synthon-DMA-DMA 13 ( $N, N$-dimethylacetamide dimethyl acetal) yielded a product having $\mathrm{m} / \mathrm{z} 288.3$ (Scheme 5). The product formation started after 1 hour and completed in 2.5-3h. The ${ }^{1} \mathrm{H}$ NMR and ${ }^{13} \mathrm{C}$ spectra of the compound had two sets of $\mathrm{NMe}_{2}$ signals at 3.10 and 3.15 as well as 37.1 and $37.3 \mathrm{ppm}$ respectively. Based on the above observations, results of DEPT experiment, as well as the 2D NOESY crosspeaks, it was suggested that a second molecule of DMA-DMA could have contributed to the $=\mathrm{C}\left(\mathrm{CH}_{3}\right)-\mathrm{NMe}_{2}$ fragment, although the stereochemistry around the double bond in the enamine substituent at position 4 could be $E$ or $Z$. The structure 14, a new heterocyclic pyrimido[1,2-a][1,3,5]triazin-6one, was assigned based on the crystal structure (Figure 4). Analogous product was obtained with 3j also. 


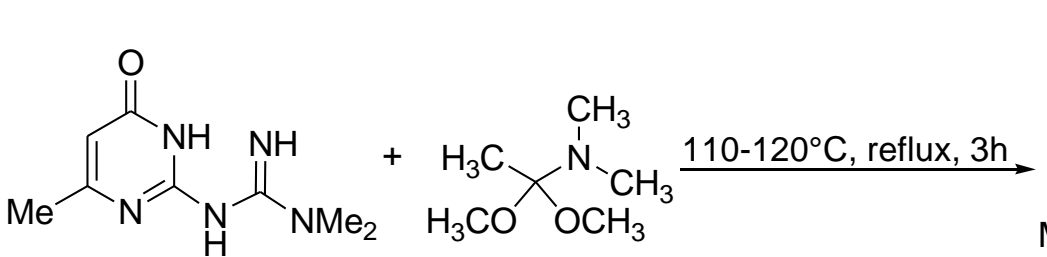

$3 \mathbf{i}$<smiles>CN/C(C)=C\c1nc(N(C)C)nc2nc(C)cc(=O)n12</smiles>

14

\section{Scheme 5}

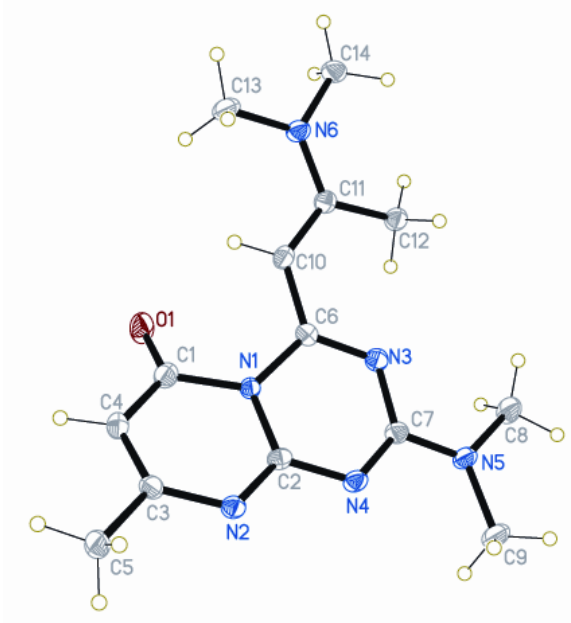

Figure 4 X-ray crystal structure of (E)-2-(dimethylamino)-4-(2-(dimethylamino)prop-1-enyl)-8methyl-6H-pyrimido[1,2-a][1,3,5]triazin-6-one 14 (displacement ellipsoids are drawn at 50\% probability level), CCDC 838638

A reaction mechanism for the formation of the product is proposed in scheme 6 . The mechanism of formation of 1,3,5-triazine $\mathbf{1 4}$ can be rationalized through the reaction with an iminium ion $\mathrm{MeC}(\mathrm{OMe})={ }^{+} \mathrm{NMe}_{2}$ derived from 13 to form the required enamine 15; this is followed by cyclisation and tautomerization with the loss of $\mathrm{HNMe}_{2}$ to give $\mathbf{4 i}$ and subsequent reaction with the electrophile from the second molecule of DMA-DMA) leading to the isolated product 14. 

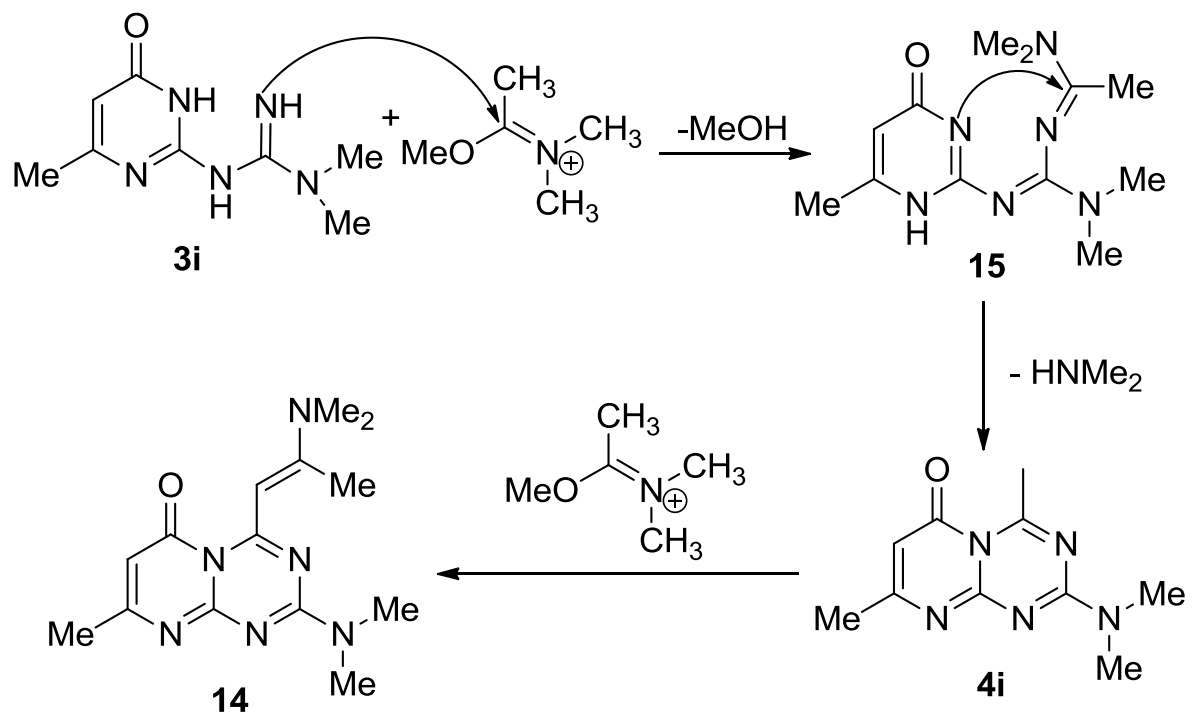

Scheme 6. Mechanistic rationale for the formation of $\mathbf{1 4}$

The comparison of bond lengths obtained from X-ray crystal structures of three pyrimido[1,2a][1,3,5]triazin-6-ones $\mathbf{6 a}, \mathbf{4 i}$ and $\mathbf{1 4}$ revealed interesting findings (Table III, supporting information). The $\mathrm{C} 4 \stackrel{-\cdots}{-} 3$ bond length ( $55--\mathrm{N} 4$ according to crystallographic numbering) in triazine ring of $4 \mathbf{i}$ was found to be unusually short (1.289 $\mathrm{A})$ suggesting higher order of double bond character whereas $\mathrm{C} 4-\mathrm{N} 5$ bond length $(\mathrm{C} 6-\mathrm{N} 1$ according to crystallographic numbering) of $\mathbf{1 4}$ was unusually large suggesting more $\mathrm{sp}^{3}$ character of bridge head nitrogen. The pyrimidine and 1,3,5-triazine rings were found to be coplanar for both $\mathbf{6 a}$ and $\mathbf{4 i}$ in the crystal structures as well as in their optimized geometries obtained from DFT calculations (vide infra). However, $\mathrm{C}=\mathrm{O}$ of pyrimidine ring bent downwards while position 4 enamine side chain of triazine ring is twisted upwards (torsional angle C1-N1-C6-N3 $=20.6^{\circ}$ ) increasing $\mathrm{O} \circ \mathrm{C} 10$ bond distance in $\mathbf{1 4}$ to $2.762 \AA$ compared to $\mathrm{O} \circ \mathrm{C} 8$ bond distance which is $2.64 \AA$. Stereochemistry of the enamine fragment at position 4 was found to be $E$.

Next, the antiproliferative activity of the synthesized compounds was assessed using MTT assay $^{19}$. In particular, lung A549 and MDA-MB-231 breast cancer cell lines were used. No 
appreciable antiproliferative activity was obtained for all the synthesized compounds except for 2-(3-chlorophenylamino)-4,8-dimethyl-6H-pyrimido[1,2-a][1,3,5]triazin-6-one $\quad(4 \mathbf{e}) \quad$ which demonstrated $\mathrm{IC}_{50}$ value of $37.5 \pm 2.8 \mu \mathrm{M}$ and $51.2 \pm 3.5 \mu \mathrm{M}$ for A549 and MDA-MB231 cell line respectively.

\section{Conclusion}

In summary, the reactions of $N$-(4-methyl-6-oxo-1,6-dihydropyrimidin-2-yl)guanidines with triethyl orthoacetate were investigated. 2-amino-4-methylpyrimido[1,2-a][1,3,5]triazin-6-ones 4 and the products of unexpected rearrangement, namely 4-amino-2-methylpyrimido[1,2a][1,3,5]triazin-6-ones $\mathbf{6}$, were obtained depending upon the starting guanidine. The rearrangement involved opening of the pyrimidine ring as was shown by isolation of acrylic acid intermediates. The requirements for the rearrangement were discussed on the basis of results obtained from experimental and theoretical studies. This approach opened the opportunities to insert different substituents at position 2 and position 4 of triazine ring, depending upon the starting guanidine. The attempt to obtain similar pyrimido[1,2- $a][1,3,5]$ triazin-6-ones using DMA-DMA was unsuccessful, as unexpected cyclocondensation product $\mathbf{1 4}$ formed as a result of overreaction. Further work is in progress to explore the propensity of the reagent to form C-C bond formation.

\section{Experimental}

General

Melting points (uncorrected) were determined on a Gallenkamp melting point apparatus. NMR spectra were recorded on a Bruker DPX-300 spectrometer using $\mathrm{Me}_{2} \mathrm{SO}-d_{6}$ as a solvent and TMS as an internal reference. IR spectra were performed on a Perkin Elmer Spectrum 100 FT-IR spectrophotometer in potassium bromide pellets. Mass spectra were obtained on a Shimadzu 
LCMS-IT-TOF system using electron spray ionization (ESI) mode. The course of the reactions was monitored by TLC on Silica gel $60 \mathrm{~F}_{254}$ plates (Merck, Germany). HPLC analysis was performed on an Agilent Eclipse XDB-C18 $(4.6 \times 250 \mathrm{~mm}, 5 \mu \mathrm{m})$ column at $30^{\circ} \mathrm{C}$, with a flow rate of $1 \mathrm{~mL} / \mathrm{min}$. 5-90\% Gradients of $\mathrm{MeOH} / \mathrm{MeCN}$ (solvent A) and $\mathrm{H}_{2} \mathrm{O}$ (solvent B) were used as mobile phases. Microwave reactions were conducted using a commercially available monomode microwave unit (CEM Discover). Elemental analyses were performed on the Perkin Elmer 2400 Elemental Analyzer Series II.

Crystal structure determinations: The single-crystal X-ray diffraction study was carried out on a Bruker APEX diffractometer attached to a CCD detector and graphite-monochromated $\mathrm{Mo}_{\mathrm{K} \alpha}$ radiation $(\lambda, 0.71073 \AA)$ using a sealed tube. Absorption corrections were made with the program $\mathrm{SADABS}^{20}$ and the crystallographic package SHELXTL ${ }^{21}$ was used for all calculations.

General method for the preparation of $\mathbf{3 a}-\mathbf{j}$

Method A Procedure 1: Into a $5 \mathrm{~mL}$ microwave vessel was added $\mathrm{N}$-(4-substituted-6-oxo-1,6dihydropyrimidin-2-yl)cyanamide (2 mmol) followed by amine hydrochloride $(2.12 \mathrm{mmol})$ and isopropanol/ACN $(1.0 \mathrm{ml})$. The vial was sealed and the mixture was irradiated at $160-170^{\circ} \mathrm{C}$ for 15 min and allowed to cool. The white solid obtained was filtered, washed with solution of sodium hydrogen carbonate and cold water and dried.

Procedure 2: Into a $5 \mathrm{~mL}$ microwave vessel was added $\mathrm{N}$-(4-substituted-6-oxo-1,6dihydropyrimidin-2-yl)cyanamide $(2 \mathrm{mmol})$, amine $(2.1 \mathrm{mmol})$ followed by the slow addition of a $2 \mathrm{~N}$ solution of TMSCl (1.04 mL, $2.1 \mathrm{mmol}, 1.1$ equiv) in $\mathrm{CH}_{3} \mathrm{CN}$ under cold conditions. After the vial was capped, reaction mixture was irradiated for $12 \mathrm{~min}$ at $160{ }^{\circ} \mathrm{C}$. After the mixture was cooled to approximately $60^{\circ} \mathrm{C}, i \mathrm{PrOH}(0.55 \mathrm{~mL}, 6 \mathrm{mmol}, 3.0$ equiv) was added. The mixture was stirred for $10 \mathrm{~s}$ and then irradiated a second time at $125^{\circ} \mathrm{C}$ for $30 \mathrm{~s}$. Upon cooling, the 
hydrochloride salts of guanidines 3 precipitated, and it was collected, washed with cold $\mathrm{CH}_{3} \mathrm{CN}$ and then with solution of sodium hydrogen carbonate and cold water and finally dried to obtain slightly better yields of pyrimidinyl guanidines.

Method B: Biguanides were synthesized according to Uohama et $\mathrm{al}^{22}$ and subsequent pyrimidine ring annulation was done using method described by Curd and Rose ${ }^{16}$.

Experimental data for some representative compounds:

$N$-(4-methyl-6-oxo-1,6-dihydropyrimidin-2-yl)guanidine (3a). Yield: 93\%; Method B; mp $>300^{\circ} \mathrm{C} ; \mathrm{lit}^{23} \mathrm{mp} 304-305^{\circ} \mathrm{C} ;{ }^{1} \mathrm{H}$ NMR $\left(300 \mathrm{MHz}, \mathrm{Me}_{2} \mathrm{SO}-d_{6}\right): \delta 2.08(3 \mathrm{H}, \mathrm{s}, \mathrm{Me}), 5.58(1 \mathrm{H}, \mathrm{s}, \mathrm{H}-$ 5), $8.03\left(4 \mathrm{H}\right.$, br. s, guanidino NHs), $11.52(1 \mathrm{H}, \mathrm{br} . \mathrm{s}, \mathrm{NH}) ;{ }^{13} \mathrm{C} \mathrm{NMR}\left(75 \mathrm{MHz}, \mathrm{Me}_{2} \mathrm{SO}-d_{6}\right): \delta$ $23.2(\mathrm{Me}), 103.0(\mathrm{CH}), 158.5,159.8,163.0$ (br. s), 166.9 (br. s).

1-(6-oxo-4-phenyl-1,6-dihydropyrimidin-2-yl)guanidine (3b). Yield: 37\%; Method B (using $\mathrm{NaOMe}$ instead of aq $\mathrm{NaOH}$ in second step); mp $273^{\circ} \mathrm{C}$ (decomposed); $1 \mathrm{lit}^{24} \mathrm{mp} 273^{\circ} \mathrm{C}$; LC-MS (APCI) $\mathrm{m} / \mathrm{z}=229.1\left(\mathrm{MH}^{+}\right) ;{ }^{1} \mathrm{H}$ NMR $\left(300 \mathrm{MHz}, \mathrm{DMSO}-d_{6}\right): \mathrm{d} 6.24(1 \mathrm{H}, \mathrm{s}, \mathrm{CH}), 7.87(2 \mathrm{H}, \mathrm{d}, J=$ $7.9 \mathrm{~Hz}, \mathrm{H}-2^{\prime}$ and $\left.\mathrm{H}-6^{\prime}\right), 7.38-7.49$ (3H, m, H-3', H-4' and $\mathrm{H}^{-5}$ '), 8.27 (4H, br. s, $\mathrm{NHC}(=\mathrm{NH}) \mathrm{NH}_{2}$ ), $11.53(1 \mathrm{H}, \mathrm{s}, \mathrm{NH})$.

N-methyl-N'-(4-methyl-6-oxo-1,6-dihydropyrimidin-2-yl)guanidine (3c). Yield 62\%; Method A (procedure 1/2); mp 272-273 ${ }^{\circ} \mathrm{C}$; TLC (silica gel, $\left.\mathrm{MeOH}: \mathrm{CH}_{2} \mathrm{Cl}_{2}, 1: 6\right): R_{\mathrm{f}} 0.38 .{ }^{1} \mathrm{H} \mathrm{NMR}(300 \mathrm{MHz}$, DMSO- $\left.d_{6}\right): \delta 2.03\left(3 \mathrm{H}, \mathrm{s}, \mathrm{CH}_{3}\right), 2.75\left(3 \mathrm{H}, \mathrm{d},{ }^{3} J=4.5 \mathrm{~Hz}, \mathrm{NCH}_{3}\right), 5.49(1 \mathrm{H}, \mathrm{s}, \mathrm{H}-5), 7.96-9.20(3 \mathrm{H}$, br. s, NH-C(=NH) NH), $10.86(1 \mathrm{H}$, br. s, NH).

1-(4-methyl-6-oxo-1,6-dihydropyrimidin-2-yl)-3-phenylguanidine (3d). Yield 90\%; Method A (procedure 1/2) or Method B; mp 248-249 ${ }^{\circ}$; lit $^{25} \mathrm{mp} 244-246^{\circ} \mathrm{C} ;{ }^{1} \mathrm{H}$ NMR (300 MHz, $\mathrm{Me}_{2} \mathrm{SO}-$ $\left.d_{6}\right): \delta 2.09(3 \mathrm{H}, \mathrm{s}, \mathrm{Me}), 5.60(1 \mathrm{H}, \mathrm{s}, \mathrm{CH}), 7.00(1 \mathrm{H}, \mathrm{t}, J=7.2 \mathrm{~Hz}, \mathrm{H}-4$ '), $7.26(2 \mathrm{H}, \mathrm{t}, J=7.5 \mathrm{~Hz}$, 
H-3' and H-5'), 7.66 (2H, d, $J=7.5 \mathrm{~Hz}, \mathrm{H}-2^{\prime}$ and H-6'), $8.12(2 \mathrm{H}$, br. s., NH-C(=NH)N), 9.04 $(1 \mathrm{H}, \mathrm{s}, \mathrm{NH}), 11.18(1 \mathrm{H}, \mathrm{s}, \mathrm{NH}) ;{ }^{13} \mathrm{C} \mathrm{NMR}\left(75 \mathrm{MHz}, \mathrm{Me}_{2} \mathrm{SO}-d_{6}\right): 23.5(\mathrm{Me}), 103.7$ (C-6), 120.3, $122.3,128.6,138.9,155.9,158.3,163.0,163.7$.

1-(3-chlorophenyl)-3-(4-methyl-6-oxo-1,6-dihydropyrimidin-2-yl)guanidine (3e). Yield 90\%; Method A (procedure 1/2) or Method B; mp 235-236 ${ }^{\circ} \mathrm{C}$; $\operatorname{lit}^{26} \mathrm{mp} 239^{\circ} \mathrm{C} ;{ }^{1} \mathrm{H} \mathrm{NMR}(300 \mathrm{MHz}$, DMSO-d $\left.)_{6}\right): \delta 2.10\left(\mathrm{~s}, 3 \mathrm{H}, \mathrm{CH}_{3}\right), 5.62(\mathrm{~s}, 1 \mathrm{H}, \mathrm{CH}), 7.02(\mathrm{dd}, 1 \mathrm{H}, J=7.9 \mathrm{~Hz}, 1.2 \mathrm{~Hz}, \mathrm{H}-4$ '), 7.26 (t, 1H, $J=8.1 \mathrm{~Hz}, \mathrm{H}-5^{\prime}$ ), 7.63 (d, 1H, $\left.J=7.9 \mathrm{~Hz}, \mathrm{H}-6^{\prime}\right), 7.75$ (s, 1H, H-2'), 8.24 (br. s., 2H, ), $9.10(\mathrm{~s}, 1 \mathrm{H}, \mathrm{NH}), 11.43(\mathrm{~s}, 1 \mathrm{H}, \mathrm{NH}) ;{ }^{13} \mathrm{C} \mathrm{NMR}\left(75 \mathrm{MHz}, \mathrm{DMSO}-d_{6}\right): 26.7\left(\mathrm{CH}_{3}\right), 107.4(\mathrm{C}-5)$, $121.8,122.5,125.2,133.4,136.3,144.0\left(\mathrm{C}-1^{\prime}\right), 158.9,161.5,166.2,167.0$.

1-(4-methoxyphenyl)-3-(4-methyl-6-oxo-1,6-dihydropyrimidin-2-yl)guanidine (3f). Yield $76 \%$; Method A (procedure 1/2) or Method B; mp 256-258 ${ }^{\circ} \mathrm{C} \mathrm{it}^{27} \mathrm{mp} 259-260^{\circ} \mathrm{C} ;{ }^{1} \mathrm{H}$ NMR $(300$ $\left.\mathrm{MHz}, \mathrm{Me}_{2} \mathrm{SO}-d_{6}\right): \delta 2.01(3 \mathrm{H}, \mathrm{s}, \mathrm{Me}), 3.72(3 \mathrm{H}, \mathrm{s}, \mathrm{OMe}), 4.35\left(2 \mathrm{H}, \mathrm{d}, J=4.9 \mathrm{~Hz}, \mathrm{CH}_{2}\right), 5.46$ (1H, s, CH), 6.89 (2H, d, J = 8.3 Hz, H-3' and H-5'), 7.28 (2H, d, J = 8.7 Hz, H-2' and H-6'), $7.82(2 \mathrm{H}$, br. s., NH-C(=NH)N), $10.67(1 \mathrm{H}, \mathrm{s}, \mathrm{NH})$.

1-(4-chlorobenzyl)-3-(4-methyl-6-oxo-1,6-dihydropyrimidin-2-yl)guanidine (3g). Yield 68\%; Method B; mp 227-228 ${ }^{\circ}$; ${ }^{1} \mathrm{H}$ NMR (300 MHz, Me $\left.2 \mathrm{SO}-d_{6}\right): \delta 2.04(3 \mathrm{H}, \mathrm{s}, \mathrm{Me}), 5.22(2 \mathrm{H}, \mathrm{s}$, $\left.\mathrm{CH}_{2}\right), 5.60(1 \mathrm{H}, \mathrm{s}, \mathrm{H}-5), 7.14(2 \mathrm{H}$, br. s, NH-C(=NH)N $), 7.33(2 \mathrm{H}, \mathrm{d}, J=8.7 \mathrm{~Hz}, \mathrm{H}-3$ ' and H-5'), $7.47\left(2 \mathrm{H}, \mathrm{d}, J=8.7 \mathrm{~Hz}, \mathrm{H}-2^{\prime}\right.$ and H-6'), $10.71\left(1 \mathrm{H}\right.$, br. s, NH); ${ }^{13} \mathrm{C}$ NMR $\left(75 \mathrm{MHz}, \mathrm{Me}_{2} \mathrm{SO}-d_{6}\right): \delta$ $23.4(\mathrm{Me}), 42.7\left(\mathrm{CH}_{2}\right), 101.3$ (C-5), 127.8 (C3' and C-5'), 130.0 (C-2' and C-4'), 131.1 (C-1'), 137.7 (C-4'), 157.5 (C-2), 159.7 (C-4), 161.0, 162.6.

N,N-dimethyl-N'-(4-methyl-6-oxo-1,6-dihydropyrimidin-2-yl)guanidine (3i). Yield 59\%; Method A (procedure 1/2) or Method B; mp 227-228 ${ }^{\circ} \mathrm{C}$; TLC (silica gel, $\mathrm{MeOH}: \mathrm{CH}_{2} \mathrm{Cl}_{2}, 1: 6$ ): $R_{\mathrm{f}}$ 0.57. ${ }^{1} \mathrm{H}$ NMR (300 MHz, DMSO-d $)$ : $\delta 2.03\left(3 \mathrm{H}, \mathrm{s}, \mathrm{CH}_{3}\right), 2.97\left(6 \mathrm{H}, \mathrm{s}, \mathrm{N}\left(\mathrm{CH}_{3}\right)_{2}\right), 5.45(1 \mathrm{H}, \mathrm{s}, \mathrm{H}-$ 
5), $8.46\left(2 \mathrm{H}\right.$, br. s, NH-C(=NH)N), $10.58\left(1 \mathrm{H}\right.$, br. s, NH); ${ }^{13} \mathrm{C}$ NMR $\left(75 \mathrm{MHz}, \mathrm{DMSO}-d_{6}\right): \delta 23.6$ $\left(\mathrm{CH}_{3}\right), 36.4\left(\mathrm{~N}\left(\mathrm{CH}_{3}\right)_{2}\right), 102.2(\mathrm{C}-5), 157.9(\mathrm{C}-2), 158.3(\mathrm{C}-4), 162.9(\mathrm{C}=\mathrm{NH}), 163.7(\mathrm{C}=\mathrm{O})$.

N-(4-methyl-6-oxo-1,6-dihydropyrimidin-2-yl)morpholine-4-carboxamidine (3j). Yield 36\%; Method A (procedure 1/2) or Method B; mp 271-272 ${ }^{\circ} \mathrm{C}(\mathrm{EtOH}) ; \mathrm{lit}^{28} \mathrm{mp} 272-273^{\circ} \mathrm{C} ;{ }^{1} \mathrm{H}$ NMR (300 MHz, $\left.\mathrm{Me}_{2} \mathrm{SO}-d_{6}\right): \delta 2.03(3 \mathrm{H}, \mathrm{s}, \mathrm{Me}), 2.75\left(3 \mathrm{H}, \mathrm{d},{ }^{3} J=4.5 \mathrm{~Hz}, \mathrm{~N} \mathrm{Me}\right), 5.49(1 \mathrm{H}, \mathrm{s}, \mathrm{H}-5)$, 7.96-9.20 (3H, br. s, NH-C(=NH) NH), $10.86(1 \mathrm{H}$, br. s, NH).

N-(4-methyl-6-oxo-1,6-dihydropyrimidin-2-yl)indoline-1-carboxamidine (3k). Yield 61\%; Method A (procedure 1/2); mp 268-269 ${ }^{\circ} \mathrm{C} ;{ }^{1} \mathrm{H}$ NMR (300 MHz, DMSO- $\left.d_{6}\right): \delta 2.10\left(3 \mathrm{H}, \mathrm{s}, \mathrm{CH}_{3}\right)$, $3.15\left(2 \mathrm{H}, \mathrm{t},{ }^{3} \mathrm{~J}=8.5 \mathrm{~Hz}, \mathrm{CH}_{2}\right), 3.97\left(2 \mathrm{H}, \mathrm{t},{ }^{3} J=8.5 \mathrm{~Hz}, \mathrm{CH}_{2}\right), 6.93\left(1 \mathrm{H}, \mathrm{t},{ }^{3} J=7.2 \mathrm{~Hz}\right), 7.09(1 \mathrm{H}$, $\left.\mathrm{t},{ }^{3} J=7.7 \mathrm{~Hz}\right), 7.17\left(1 \mathrm{H}, \mathrm{d},{ }^{3} J=7.2 \mathrm{~Hz}\right), 8.64\left(1 \mathrm{H}, \mathrm{d},{ }^{3} J=8.3 \mathrm{~Hz}\right), 11.24(1 \mathrm{H}, \mathrm{s}, \mathrm{NH}) .{ }^{13} \mathrm{C}$ NMR (75 MHz, DMSO-d $\left.d_{6}\right): \delta 23.5\left(\mathrm{CH}_{3}\right), 26.4\left(3^{\prime}-\mathrm{CH}_{2}\right), 47.3\left(2^{\prime}-\mathrm{CH}_{2}\right), 103.5(\mathrm{C}-5), 118.1,122.1$, 124.1, 126.9, 131.6, 142.4, $157.9(\mathrm{C}-2), 155.3(\mathrm{C}-4), 162.7(\mathrm{C}=\mathrm{NH}), 163.7(\mathrm{C}=\mathrm{O})$.

1-(3-bromophenyl)-3-(6-oxo-4-(trifluoromethyl)-1,6-dihydropyrimidin-2-yl)guanidine

Yield 70\%; mp 161-162 ${ }^{\circ} \mathrm{C}(\mathrm{EtOH}) ;{ }^{1} \mathrm{H}$ NMR $\left(300 \mathrm{MHz}, \mathrm{Me}_{2} \mathrm{SO}-d_{6}\right): \delta 6.18(1 \mathrm{H}, \mathrm{s}, \mathrm{H}-7), 7.12-$ $7.28\left(2 \mathrm{H}, \mathrm{m}, \mathrm{H}_{\mathrm{Ar}}\right), 7.74-7.89\left(2 \mathrm{H}, \mathrm{m}, \mathrm{H}_{\mathrm{Ar}}\right), 8.32(1 \mathrm{H}$, br. s., $\mathrm{NH}), 10.19(1 \mathrm{H}$, br. s., $\mathrm{NH}), 12.05$ (1H, br. s., NH); ${ }^{13} \mathrm{C}$ NMR (75 MHz, $\left.\mathrm{Me}_{2} \mathrm{SO}-d_{6}\right): \delta 103.4$ (q, $\left.{ }^{3} J_{\mathrm{C}-\mathrm{F}}=3.1 \mathrm{~Hz}, \mathrm{C}-7\right), 119.1,120.9$ $\left(\mathrm{q},{ }^{1} J_{\mathrm{C}-\mathrm{F}}=274.4 \mathrm{~Hz}, \mathrm{CF}_{3}\right), 121.4,121.9,122.8,125.0,130.4,140.8,150.9\left(\mathrm{q},{ }^{2} J_{\mathrm{C}-\mathrm{F}}=33.3 \mathrm{~Hz}, \mathrm{C}-\right.$ $8), 156.2,159.5,163.4$

\section{N-(4-methyl-6-oxo-1,6-dihydropyrimidin-2-yl)cyanamide (1).}

Yield 61\%; mp >300 ${ }^{\circ} \mathrm{C}$; lit ${ }^{29} \mathrm{mp}>300{ }^{\circ} \mathrm{C}$; TLC (silica gel, $\mathrm{MeOH}: \mathrm{CH}_{2} \mathrm{Cl}_{2}, 1: 6$ ): $R_{f} 0.43 .{ }^{1} \mathrm{H}$ NMR (300 MHz, Me 2 SO- $\left.d_{6}\right): \delta 1.93(3 \mathrm{H}, \mathrm{s}, \mathrm{Me}), 5.20(1 \mathrm{H}, \mathrm{s}, \mathrm{C}-5), 10.22(1 \mathrm{H}, \mathrm{s}, \mathrm{NH}) ;{ }^{13} \mathrm{C}$ NMR (75 MHz, Me $\left.\mathrm{Me}_{2} \mathrm{SO}-d_{6}\right): \delta 23.8(\mathrm{Me}), 98.7(\mathrm{C}-5), 120.9(\mathrm{CN}), 161.6(\mathrm{C}-2), 164.4(\mathrm{C}-4), 165.6$ $(\mathrm{C}=\mathrm{O})$. 
General method for the preparation of 8(2)substituted 4(8)-methylpyrimido[1,2-a][1,3,5] triazin6(4)-ones 4 or $\mathbf{6}$ :

Guanidines (3a-j), $0.25 \mathrm{ml}$ acetic acid and excess triethylorthoacetate were refluxed under nitrogen atmosphere for $0.3-9 \mathrm{~h}$. Solvent was evaporated to dryness on rotary evaporator, purified using column chromatography and finally recrystallised using suitable solvent.

4,8-dimethyl-2-(phenylamino)-6H-pyrimido[1,2-a][1,3,5]triazin-6-one (4d). mp 220-22 ${ }^{\circ} \mathrm{C}$ (AcOEt); TLC (silica gel, 9:1 AcOEt:Hex): $R_{f}$ 0.53; LC-MS (ESI) m/z $268.1141\left(\mathrm{MH}^{+}\right)$; Anal. Calcd. for $\mathrm{C}_{14} \mathrm{H}_{13} \mathrm{~N}_{5} \mathrm{O}$ : C, 62.91; H, 4.90; N, 26.20; Found 62.61, 4.95, 26.03. ${ }^{1} \mathrm{H}$ NMR (300 $\left.\mathrm{MHz}, \mathrm{Me}_{2} \mathrm{SO}-d_{6}\right): \delta 2.18(3 \mathrm{H}, \mathrm{s}, 8-\mathrm{Me}), 2.90(3 \mathrm{H}, \mathrm{s}, 4-\mathrm{Me}), 5.92(1 \mathrm{H}, \mathrm{s}, \mathrm{H}-7), 7.13\left(1 \mathrm{H}, \mathrm{t},{ }^{3} \mathrm{~J}=\right.$ $\left.7.4 \mathrm{~Hz}, \mathrm{H}-5^{\prime}\right), 7.38\left(2 \mathrm{H}, \mathrm{t},{ }^{3} J=7.7 \mathrm{~Hz}, \mathrm{H}-3^{\prime}\right.$ and $\left.\mathrm{H}-5^{\prime}\right), 7.86\left(2 \mathrm{H}, \mathrm{d},{ }^{3} J=7.5 \mathrm{~Hz}, \mathrm{H}-2^{\prime}\right.$ and H-6'), $10.63(1 \mathrm{H}, \mathrm{s}, \mathrm{NH}) ;{ }^{13} \mathrm{C}$ NMR (75 MHz, Me $\left.2 \mathrm{SO}-d_{6}\right): \delta 23.7$ (2-Me), $26.2(8-\mathrm{Me}), 103.6(\mathrm{C}-5)$, 120.4 (C-2' and C-6'), 123.9 (C-4'), 128.6 (C-3' and C-5'), 138.0 (C-1'), 152.9, 156.8 (C-2), 160.0, 163.8, 166.7; IR (KBr); v 3109 br NH, 1685 C=O, 1627, 1535, 1244, 1036, 821, 752.

2-(3-chlorophenylamino)-4,8-dimethyl-6H-pyrimido[1,2-a][1,3,5]triazin-6-one (4e). mp 239$240^{\circ} \mathrm{C}$ (AcOEt); TLC (silica gel, 9:1 AcOEt:Hex): $R_{f} 0.60 ; \mathrm{LC}-\mathrm{MS}(\mathrm{ESI}) \mathrm{m} / \mathrm{z} 302.0708\left(\mathrm{MH}^{+}\right) ;$ Anal. Calcd. for $\mathrm{C}_{14} \mathrm{H}_{12} \mathrm{ClN}_{5} \mathrm{O}$ : C, 55.73; H, 4.01; Cl, 11.75; N, 23.21; Found: C, 55.49; H, 4.05; Cl 11.50; N, 22.98. ${ }^{1} \mathrm{H}$ NMR (300 MHz, $\left.\mathrm{Me}_{2} \mathrm{SO}-d_{6}\right): \delta 2.19$ (1H, s, 8-Me), $2.91(1 \mathrm{H}, \mathrm{s}, 4-\mathrm{Me})$, $5.96(1 \mathrm{H}, \mathrm{s}, \mathrm{H}-7), 7.18(1 \mathrm{H}, \mathrm{d}, J=8.3 \mathrm{~Hz}, \mathrm{H}-4$ ') $7.40(1 \mathrm{H}, \mathrm{t}, J=8.1 \mathrm{~Hz}, \mathrm{H}-5$ ') $7.76(1 \mathrm{H}, \mathrm{d}, J=$ $7.9 \mathrm{~Hz}, \mathrm{H}-6$ '), $8.06\left(1 \mathrm{H}, \mathrm{s}, \mathrm{H}-2\right.$ '), $10.79(1 \mathrm{H}, \mathrm{s}, \mathrm{NH}) ;{ }^{13} \mathrm{C} \mathrm{NMR}\left(75 \mathrm{MHz}, \mathrm{Me}_{2} \mathrm{SO}-d_{6}\right): 23.8(8-$ Me), 26.2 (4-Me), 104.0 (C-7), 118.7, 119.5, 123.5, 130.3, 133.0, 139.7 (C-1'), 152.7, 156.9, 160.0, 164.3, 166.7; IR (KBr); v 3273 br NH, 3103 (CH), 3082, 1678 C=O, 1636, 1095, 866, 788, 
717.

2-(4-methoxyphenylamino)-4,8-dimethyl-6H-pyrimido[1,2-a][1,3,5]triazin-6-one $\quad(4 \mathrm{f}) . \quad \mathrm{mp}$ 177-178 ${ }^{\circ} \mathrm{C}$ (AcOEt); TLC (silica gel, 9:1 Hex:AcOEt): $R_{f}$ 0.25; LC-MS (ESI) m/z 298.1296 $\left(\mathrm{MH}^{+}\right)$; Anal. Calcd. for $\mathrm{C}_{15} \mathrm{H}_{15} \mathrm{~N}_{5} \mathrm{O}_{2}: \mathrm{C}, 60.60 ; \mathrm{H}, 5.09 ; \mathrm{N}, 23.56$. Found: $\mathrm{C}, 60.47 ; \mathrm{H}, 5.10 ; \mathrm{N}$,

23.29. ${ }^{1} \mathrm{H}$ NMR $\left(300 \mathrm{MHz}, \mathrm{Me}_{2} \mathrm{SO}-d_{6}\right): \delta 2.16(3 \mathrm{H}, \mathrm{s}, 8-\mathrm{Me}), 2.88(3 \mathrm{H}, \mathrm{s}, 4-\mathrm{Me}), 3.75(3 \mathrm{H}, \mathrm{s}$, OMe), 5.89 (1H, s, H-7), 6.96 (2H, d, $J=8.8 \mathrm{~Hz}, \mathrm{H}-3$ ' and H-5'), $7.74\left(2 \mathrm{H}, \mathrm{d}, J=8.8 \mathrm{~Hz}, \mathrm{H}-2^{\prime}\right.$ and H-6'), 10.52 (1H, s, NH); ${ }^{13} \mathrm{C}$ NMR (75 MHz, $\mathrm{Me}_{2} \mathrm{SO}-d_{6}$ ): 23.7 (4-Me), 26.2 (8-Me), 55.2 (OMe), 103.2 (C-7), 113.8 (C-2' and C-6'), 122.1 (C-3' and C-5'), 130.9 (C-1'), 153.1 (C-4'), 155.8, 156.5, 160.1, 163.5, 166.7; IR (KBr); v 3109, $2920(\mathrm{CH}), 2850,1670 \mathrm{C}=\mathrm{O}, 1627,1541$, $1419,1236,1174,1028,831,788$.

2-(dimethylamino)-4,8-dimethyl-6H-pyrimido[1,2-a][1,3,5]triazin-6-one (4i). mp $190-191^{\circ} \mathrm{C}$ (AcOEt); TLC (silica gel, $\left.\mathrm{CH}_{2} \mathrm{Cl}_{2}\right): R_{f} 0.30$; LC-MS (ESI) m/z $220.1198\left(\mathrm{MH}^{+}\right.$); Anal. Calcd for $\mathrm{C}_{10} \mathrm{H}_{13} \mathrm{~N}_{5} \mathrm{O}: \mathrm{C}, 54.78 ; \mathrm{H}, 5.98 ; \mathrm{N}, 31.94$; found: $\mathrm{C}, 54.42 ; \mathrm{H}, 5.87 ; \mathrm{N}, 31.69 .{ }^{1} \mathrm{H}$ NMR $(300 \mathrm{MHz}$, $\left.\mathrm{Me}_{2} \mathrm{SO}-d_{6}\right): \delta 2.12(3 \mathrm{H}, \mathrm{s}, 8-\mathrm{Me}), 2.85$ (3H, s, 4-Me), $3.14\left(3 \mathrm{H}, \mathrm{s}, \mathrm{N}(\mathrm{Me})_{2}\right), 3.25\left(3 \mathrm{H}, \mathrm{s}, \mathrm{N}(\mathrm{Me})_{2}\right)$, $5.78(1 \mathrm{H}, \mathrm{s}, \mathrm{H}-7) ;{ }^{13} \mathrm{C}$ NMR (75 MHz, Me $\left.2 \mathrm{SO}-d_{6}\right): \delta 23.8(8-\mathrm{Me}), 26.6(4-\mathrm{Me}), 36.3\left(\mathrm{~N}(\mathrm{Me})_{2}\right.$, $36.4\left(\mathrm{~N}(\mathrm{Me})_{2}, 101.8(\mathrm{C}-7), 153.1,158.0,160.1,163.5,167.2(\mathrm{C}=\mathrm{O})\right.$. ; IR (KBr); v 3420 br NH, $3034(\mathrm{CH}), 2978,1714,1670 \mathrm{C}=\mathrm{O}, 1620,1516,1317,1238,1192,1078,1033,966,825,794$, 717.

4,8-dimethyl-2-morpholino-6H-pyrimido[1,2-a][1,3,5]triazin-6-one (4j). mp 191-192 ${ }^{\circ} \mathrm{C}$; TLC (silica gel, 9:1 $\left.\mathrm{CH}_{2} \mathrm{Cl}_{2}\right): R_{f}$ 0.40; LC-MS (ESI) m/z $262\left(\mathrm{MH}^{+}\right.$); Anal. Calcd for $\mathrm{C}_{12} \mathrm{H}_{15} \mathrm{~N}_{5} \mathrm{O}_{2}: \mathrm{C}$, 55.16; H, 5.79; N, 26.80; found C, 55.22; H, 5.77; N, 26.86. ${ }^{1} \mathrm{H}$ NMR (300 MHz, $\left.\mathrm{Me}_{2} \mathrm{SO}-d_{6}\right): \delta$ $2.13(3 \mathrm{H}, \mathrm{s}, 8-\mathrm{Me}), 2.86(3 \mathrm{H}, \mathrm{s}, 4-\mathrm{Me}), 3.67\left(\mathrm{t}, J=4.5 \mathrm{~Hz}, 4 \mathrm{H},\left(\mathrm{CH}_{2}\right)_{2} \mathrm{O}\right), 3.78(\mathrm{t}, J=4.3 \mathrm{~Hz}, 2 \mathrm{H}$, 
$\mathrm{N}\left(\mathrm{CH}_{2}\right), 3.89$ (t, $J=4.3 \mathrm{~Hz}, 2 \mathrm{H}, \mathrm{N}\left(\mathrm{CH}_{2}\right), 5.81(\mathrm{~s}, 1 \mathrm{H}, \mathrm{H}-7) ;{ }^{13} \mathrm{C} \mathrm{NMR}\left(75 \mathrm{MHz}, \mathrm{Me}_{2} \mathrm{SO}-d_{6}\right): \delta$ 25.0 (8-Me), 27.8 (4-Me), $44.8\left(\mathrm{CH}_{2}\right), 45.3\left(\mathrm{CH}_{2}\right), 66.7\left(\mathrm{CH}_{2}\right), 67.1\left(\mathrm{CH}_{2}\right), 103.3(\mathrm{C}-7), 154.4$, 158.3, 161.2, 165.5, $168.3(\mathrm{C}=\mathrm{O})$; IR (KBr); v 3388 br NH, $3076(\mathrm{CH}), 2950,1627 \mathrm{C}=\mathrm{O}, 1543$, $1508,1406,1352,1246,1181,1028,966,834$.

2-(indolin-1-yl)-4,8-dimethyl-6H-pyrimido[1,2-a][1,3,5]triazin-6-one $\quad(\mathbf{4 k}) . \quad \mathrm{mp} \quad 212-213^{\circ} \mathrm{C}$ (AcOEt); TLC (silica gel, 9:1 AcOEt:Hex): $R_{f}$ 0.32; Anal. Calcd for $\mathrm{C}_{16} \mathrm{H}_{15} \mathrm{~N}_{5} \mathrm{O}: \mathrm{C}, 65.52 ; \mathrm{H}$, 5.15; N, 23.88; found C, 65.27; H, 5.14; N, 23.74. ${ }^{1} \mathrm{H}$ NMR (300 MHz, $\left.\mathrm{Me}_{2} \mathrm{SO}-d_{6}\right): \delta 2.18(3 \mathrm{H}, \mathrm{s}$, 8-Me) and $2.21(3 \mathrm{H}, \mathrm{s}, 8-\mathrm{Me}), 2.94(3 \mathrm{H}, \mathrm{s}, 4-\mathrm{Me})$ and $3.00(3 \mathrm{H}, \mathrm{s}, 4-\mathrm{Me}), 3.20\left(2 \mathrm{H}, \mathrm{t},{ }^{3} J=8.5\right.$ $\left.\mathrm{Hz}, 3^{\prime} \mathrm{CH}_{2}\right), 4.19\left(1 \mathrm{H}, \mathrm{t},{ }^{3} J=8.3 \mathrm{~Hz}, \mathrm{CH}_{2}\right)$ and $4.32\left(1 \mathrm{H}, \mathrm{t},{ }^{3} J=8.9 \mathrm{~Hz}, \mathrm{CH}_{2}\right), 5.92(2 \mathrm{H}, \mathrm{s}, \mathrm{CH})$, 6.98-7.16 (2H, m, H-4'), 7.21-7.40 (4H, m, H-5' and H-6'), 8.29 (1H, d, $\left.{ }^{3} J=8.2 \mathrm{~Hz}, \mathrm{H}-7^{\prime}\right), 8.49$ $\left(1 \mathrm{H}, \mathrm{d},{ }^{3} J=8.1 \mathrm{~Hz}, \mathrm{H}-7^{\prime}\right) ;{ }^{13} \mathrm{C}$ NMR $\left(75 \mathrm{MHz}, \mathrm{Me}_{2} \mathrm{SO}-d_{6}\right): \delta 23.5(\mathrm{Me}), 26.4\left(3^{\prime}-\mathrm{CH}_{2}\right), 47.3\left(2^{\prime}-\right.$ $\left.\mathrm{CH}_{2}\right), 103.5$ (C-5), 118.1, 122.1, 124.1, 126.9, 131.6, 142.4, 157.9 (C-2), 155.3 (C-4), 162.7 (C=NH), $163.7(\mathrm{C}=\mathrm{O})$. IR (KBr); v 3446 br NH, $2935(\mathrm{CH}), 2918,2854,1707 \mathrm{C}=\mathrm{O}, 1624,1576$, 1481, 1456, 1249, 1195, 785.1.

2-(3-bromophenylamino)-4-methyl-8-(trifluoromethyl)-6H-pyrimido[1,2-a][1,3,5]triazin-6one (4l). Yield: $70 \%$; mp 216- $217^{\circ} \mathrm{C}(\mathrm{EtOH})$; TLC (silica gel, 9:1 AcOEt:Hex): $R_{f} 0.90 .{ }^{1} \mathrm{H}$ NMR (300 MHz, $\left.\mathrm{Me}_{2} \mathrm{SO}-d_{6}\right): \delta 2.91(1 \mathrm{H}, \mathrm{s}, \mathrm{Me}), 6.54(1 \mathrm{H}, \mathrm{s}, \mathrm{H}-7), 7.32-7.42(2 \mathrm{H}, \mathrm{m}, \mathrm{H}-4$ ' and H-5'), $7.86\left(1 \mathrm{H}, \mathrm{d},{ }^{3} \mathrm{~J}=6.8 \mathrm{~Hz}, \mathrm{H}-6^{\prime}\right), 8.10\left(1 \mathrm{H}, \mathrm{s}, \mathrm{H}-2^{\prime}\right), 11.08(1 \mathrm{H}, \mathrm{s}, \mathrm{NH}) ; 26.07\left(\mathrm{CH}_{3}\right),(\mathrm{C}-4), 103.3$ $\left(\mathrm{q},{ }^{3} J_{\mathrm{C}-\mathrm{F}}=2.6 \mathrm{~Hz}, \mathrm{C}-7\right), 119.5,120.6\left(\mathrm{q},{ }_{\mathrm{C}-\mathrm{F}}=275.4 \mathrm{~Hz}, \mathrm{CF}_{3}\right), 121.5,122.8,127.1,130.8,139.2$, $152.6\left(\mathrm{q},{ }^{2} J_{\mathrm{C}-\mathrm{F}}=34.0 \mathrm{~Hz}, \mathrm{C}-8\right), 155.1,157.2,160.2,164.4$; IR (KBr); v $3282 \mathrm{NH}, 3081,2945$, $1699 \mathrm{C}=\mathrm{O}, 1631,1608,1587,1552,1465,1375,1340,1278,1192,1155,1101,1083,925,875$, 788,$707 ; \%$ purity $>95 \% \mathrm{t}_{\mathrm{R}}=7.1 \mathrm{~min}$.

4-amino-2,8-dimethyl-6H-pyrimido[1,2-a $][\mathbf{1 , 3 , 5}]$ triazin-6-one (6a). mp 264-265 ${ }^{\circ} \mathrm{C} ; \quad \mathrm{TLC}$ 
(silica gel, $\mathrm{CH}_{2} \mathrm{Cl}_{2}$ ): $R_{f}$ 0.55; LC-MS (ESI) m/z $192.0841\left(\mathrm{MH}^{+}\right)$; Anal. Calcd for $\mathrm{C}_{8} \mathrm{H}_{9} \mathrm{~N}_{5} \mathrm{O}: \mathrm{C}$, 50.26; H, 4.74; N, 36.63; found: C, 50.35, H, 4.95, N, 36.03. ${ }^{1} \mathrm{H}$ NMR (300 MHz, $\left.\mathrm{Me}_{2} \mathrm{SO}-d_{6}\right): \delta$ $2.18(1 \mathrm{H}, \mathrm{s}, 2-\mathrm{Me}), 2.24(1 \mathrm{H}, \mathrm{s}, 8-\mathrm{Me}), 6.04(1 \mathrm{H}, \mathrm{s}, \mathrm{H}-7), 9.26(1 \mathrm{H}, \mathrm{s}, \mathrm{NH}), 10.18(1 \mathrm{H}, \mathrm{s}, \mathrm{NH})$; ${ }^{13} \mathrm{C}$ NMR (75 MHz, $\left.\mathrm{Me}_{2} \mathrm{SO}-d_{6}\right): 23.8$ (8-Me), 25.2 (2-Me), 104.6 (C-7), 152.9, 156.8, 162.7, 167.6, 172.7; IR (KBr); v 3294 NH, 3116 br, 1695 C=O, 1647, 1575, 1400, 1197, 1170, 1060, $821,792,748,702$.

4-amino-2-methyl-8-phenyl-6H-pyrimido[1,2-a][1,3,5]triazin-6-one (6b). Yield: $58 \%$; $\mathrm{mp}$ 258-259 ${ }^{\circ} \mathrm{C}(80 \mathrm{AcOEt}: 20 \mathrm{Hex})$; TLC (silica gel, 9:1 AcOEt:Hex): $R_{f} 0.45 ; .{ }^{1} \mathrm{H} \mathrm{NMR}(300 \mathrm{MHz}$, $\left.\mathrm{Me}_{2} \mathrm{SO}-d_{6}\right): \delta 2.29\left(1 \mathrm{H}, \mathrm{s}, 2-\mathrm{CH}_{3}\right), 6.77$ (1H, s, H-7), 7.44-7.61 (3H, m, H-3', H-4', H-5'), 8.12 $\left(2 \mathrm{H}, \mathrm{d}, J=8.1 \mathrm{~Hz}, \mathrm{H}-2^{\prime}\right.$ and H-6'), $9.32(1 \mathrm{H}, \mathrm{s}, \mathrm{NH}), 10.22(1 \mathrm{H}, \mathrm{s}, \mathrm{NH}) ;{ }^{13} \mathrm{C}$ NMR $(75 \mathrm{MHz}$, $\left.\mathrm{Me}_{2} \mathrm{SO}-d_{6}\right): 25.2\left(2-\mathrm{CH}_{3}\right), 101.2(\mathrm{C}-7), 127.1,128.6,131.1,135.6(\mathrm{C}-1$ ') $, 153.4,156.8,162.3$, 163.6, 172.9; IR (KBr); v 3344 NH, 3213, 1674 C=O, 1624, 1570, 1544, 1448, 1382, 1220, 1174 , 908,$778 ; \%$ purity $>95 \% ; \mathrm{t}_{\mathrm{R}} 8.9 \mathrm{~min}$

2,8-dimethyl-4-(methylamino)-6H-pyrimido[1,2-a][1,3,5]triazin-6-one (6c). mp $166-167^{\circ} \mathrm{C}$ (AcOEt); TLC (silica gel, 9:1 AcOEt:Hex): $R_{f}$ 0.16; LC-MS (ESI) m/z $206.0946\left(\mathrm{MH}^{+}\right)$; Anal. Calcd. for $\mathrm{C}_{9} \mathrm{H}_{11} \mathrm{~N}_{5} \mathrm{O}$ : C, 52.67; H, 5.40; N, 34.13; found: C, 52.49, H, 5.69, N, 32.83. ${ }^{1} \mathrm{H}$ NMR (300 MHz, $\left.\mathrm{Me}_{2} \mathrm{SO}-d_{6}\right): \delta 2.18(3 \mathrm{H}, \mathrm{s}, 2-\mathrm{Me}), 2.28(3 \mathrm{H}, \mathrm{s}, 8-\mathrm{Me}), 2.98(3 \mathrm{H}, \mathrm{d}, J=4.9 \mathrm{~Hz}, \mathrm{NMe})$, $6.07(1 \mathrm{H}, \mathrm{s}, \mathrm{H}-7), 10.90(1 \mathrm{H}, \mathrm{d}, J=4.5 \mathrm{~Hz}, \mathrm{NH}) ;{ }^{13} \mathrm{C} \mathrm{NMR}\left(75 \mathrm{MHz}, \mathrm{Me}_{2} \mathrm{SO}-d_{6}\right): 23.7(8-\mathrm{Me})$, 25.6 (2-Me), 28.4 (NMe), 104.8 (C-7), 152.6, 155.5, 163.0, 167.5, 172.3; IR (KBr); v $3324 \mathrm{NH,}$ 3201, $1690 \mathrm{C}=\mathrm{O}, 1642,1574,1440,1187,1165,1065,793,774$.

4-(4-chlorobenzylamino)-2,8-dimethyl-6H-pyrimido[1,2-a][1,3,5]triazin-6-one (6g). mp 133134 ${ }^{\circ} \mathrm{C}$; TLC (silica gel, 9:1 AcOEt:Hex): $R_{f} 0.8 ;$ LC-MS (ESI) m/z $316.0817\left(\mathrm{MH}^{+}\right)$; Anal. Calcd for $\mathrm{C}_{15} \mathrm{H}_{14} \mathrm{ClN}_{5} \mathrm{O}: \mathrm{C}, 57.06 ; \mathrm{H}, 4.47 ; \mathrm{Cl}, 11.23 ; \mathrm{N}, 22.18$; found $\mathrm{C}, 56.99 ; \mathrm{H}, 4.51 ; \mathrm{Cl} 11.44 ; \mathrm{N}$, 
22.05. ${ }^{1} \mathrm{H}$ NMR (300 MHz, Me $\left.2 \mathrm{SO}-d_{6}\right): \delta 2.19$ (3H, s , 8-Me), 2.25 (3H, s, 2-Me), 4.69 (2H, s, $\left.\mathrm{CH}_{2}\right), 6.08$ (1H, s, H-7), 7.39 (2H, d, $J=8.7 \mathrm{~Hz}, \mathrm{H}-3$ ' and H-5'), 7.43 (2H, d, $J=8.7 \mathrm{~Hz}, \mathrm{H}-2^{\prime}$ and H-6'), 11.43 (1H, br. s., NH); ${ }^{13} \mathrm{C}$ NMR (75 MHz, Me $\left.2 \mathrm{SO}-d_{6}\right): 23.8$ (2-Me), 25.6 (8-Me), $43.9\left(\mathrm{CH}_{2}\right), 105.0$ (C-7), 128.3 (C-3' and C-5'), 129.5 (C-2' and C-6'), 131.8 (C-4'), 136.4 (C-1'), 152.7, 155.2, 163.2, 167.6, 172.3. ; IR (KBr); v 3170 br NH, 1689 C=O, 1618, 1411, 1377, 1344, $827,794,711$.

4-(4-methoxybenzylamino)-2,8-dimethyl-6H-pyrimido[1,2-a][1,3,5]triazin-6-one $\quad(6 \mathrm{~h}) . \mathrm{mp}$ 138-139 ${ }^{\circ}$; TLC (silica gel, 9:1 AcOEt:Hex): $R_{f}$ 0.26; LC-MS (ESI) m/z 312.1409 $\left(\mathrm{MH}^{+}\right.$); Anal. Calcd. for $\mathrm{C}_{16} \mathrm{H}_{17} \mathrm{~N}_{5} \mathrm{O}_{2}$ : C, 61.72; H, 5.50; N, 22.49; found: $\mathrm{C}, 61.78 ; \mathrm{H}, 5.42 ; \mathrm{N}, 22.52 .{ }^{1} \mathrm{H}$ NMR (300 MHz, $\left.\mathrm{Me}_{2} \mathrm{SO}-d_{6}\right): \delta 2.19(3 \mathrm{H}, \mathrm{s}, 2-\mathrm{Me}), 2.28(3 \mathrm{H}, \mathrm{s}, 8-\mathrm{Me}), 3.74(3 \mathrm{H}, \mathrm{s}, \mathrm{OMe}), 4.62(2 \mathrm{H}, \mathrm{d}$, $\left.J=5.7 \mathrm{~Hz}, \mathrm{CH}_{2}\right), 6.07(1 \mathrm{H}, \mathrm{s}, \mathrm{H}-3), 6.91\left(1 \mathrm{H}, \mathrm{d}, J=8.7 \mathrm{~Hz}, \mathrm{H}-3^{\prime}\right.$ and $\left.\mathrm{H}-5^{\prime}\right), 7.34(1 \mathrm{H}, \mathrm{d}, J=8.3$ $\mathrm{Hz}, \mathrm{H}-2^{\prime}$ and H-6'), $11.36(1 \mathrm{H}, \mathrm{t}, J=5.7 \mathrm{~Hz}, \mathrm{NH}) ;{ }^{13} \mathrm{C} \mathrm{NMR}\left(75 \mathrm{MHz}, \mathrm{Me}_{2} \mathrm{SO}-d_{6}\right): 23.8$ (8-Me), 25.6 (2-Me), $44.1\left(\mathrm{CH}_{2}\right), 55.0(\mathrm{OMe}), 104.9$ (C-7), 113.8 (C-2' and C-6'), 128.9 (C-1'), 129.2 (C3' and C-5'), 152.6 (C-4'), 155.1, 158.6, 163.3, 167.7, 172.4; IR (KBr); v 3109 br NH, 2950 (CH), $1683 \mathrm{C}=\mathrm{O}, 1629,1516,1458,1379,1342,1172,1114,1026,821,792$.

3-(6-methyl-4-(phenylamino)-1,3,5-triazin-2(1H)-ylideneamino)but-2-enoic acid (6'd).

LC-MS (ESI) m/z 285.1293 $\left(\mathrm{MH}^{+}\right)$; TLC (silica gel, 9:1 AcOEt:Hex): $R_{f}$ 0.16; Anal. Calcd for $\mathrm{C}_{14} \mathrm{H}_{15} \mathrm{~N}_{5} \mathrm{O}_{2}$ : C, 58.94; H, 5.30; N, 24.55; found 56.18, H 4.89, N 23.58; ${ }^{1} \mathrm{H}$ NMR (300 MHz, $\left.\mathrm{Me}_{2} \mathrm{SO}-d_{6}\right): \delta 2.17(3 \mathrm{H}, \mathrm{s}, 8-\mathrm{Me}), 2.25(3 \mathrm{H}, \mathrm{s}, 4-\mathrm{Me}), 5.77(1 \mathrm{H}, \mathrm{s}, \mathrm{CH}), 7.13(1 \mathrm{H}, \mathrm{t}, J=7.3 \mathrm{~Hz}$, H-4'), 7.33 (2H, t, $J=7.7 \mathrm{~Hz}, \mathrm{H}-3^{\prime}$ ' and H-5'), 7.84 (2H, d, $J=7.9 \mathrm{~Hz}, \mathrm{H}-2^{\prime}$ and H-6'), 10.94 (1H, s, NHPh), 12.06 (1H, br s, NH), 13.75 (1H, br s, COOH).

3-(4-(4-methoxyphenylamino)-6-methyl-1,3,5-triazin-2(1H)-ylideneamino)but-2-enoic acid (6'f). LC-MS (ESI) m/z 316.1255 $\left(\mathrm{MH}^{+}\right)$; TLC (silica gel, 9:1 Hex:AcOEt): $R_{f}$ 0.11; Anal. Calcd 
for $\mathrm{C}_{15} \mathrm{H}_{17} \mathrm{~N}_{5} \mathrm{O}_{3}$ : C, 57.13; H, 5.43; N, 22.21; found $\mathrm{C}, 57.44 ; \mathrm{H}, 5.21 ; \mathrm{N}, 22.45 .{ }^{1} \mathrm{H}$ NMR (300 MHz, $\left.\mathrm{Me}_{2} \mathrm{SO}-d_{6}\right): \delta 2.17(3 \mathrm{H}, \mathrm{s}, 8-\mathrm{Me}), 2.24$ (3H, s, 4-Me), 3.75 (3H, s, OMe), $5.74(1 \mathrm{H}, \mathrm{s}, \mathrm{CH})$, $6.87(2 \mathrm{H}, \mathrm{d}, J=8.3 \mathrm{~Hz}, \mathrm{H}-2$ ' and H-6'), $7.74(2 \mathrm{H}, \mathrm{d}, J=9.0 \mathrm{~Hz}, \mathrm{H}-3$ 'and H-5'), $10.82(1 \mathrm{H}, \mathrm{s}$, NHPh), 11.97 (1H, s, NH), $13.72(1 \mathrm{H}, \mathrm{s}, \mathrm{COOH})$.

3-(4-(4-methoxybenzylamino)-6-methyl-1,3,5-triazin-2(1H)-ylideneamino)but-2-enoic acid (6'h). ${ }^{1} \mathrm{H}$ NMR (300 MHz, Me $\left.2 \mathrm{SO}-d_{6}\right): \delta 2.12(3 \mathrm{H}, \mathrm{s}, 4-\mathrm{Me}), 2.17(3 \mathrm{H}, \mathrm{s}, \mathrm{Me}), 3.74(3 \mathrm{H}, \mathrm{s}$, OMe), $4.57\left(2 \mathrm{H}, \mathrm{d}, J=5.7 \mathrm{~Hz}, \mathrm{CH}_{2}\right), 5.66(1 \mathrm{H}, \mathrm{s}, \mathrm{H}-3), 7.37(2 \mathrm{H}, \mathrm{d}, J=8.7 \mathrm{~Hz}, \mathrm{H}-3$ ' and $\mathrm{H}-5$ '), $7.48\left(1 \mathrm{H}, \mathrm{d}, J=8.3 \mathrm{~Hz}, \mathrm{H}-2^{\prime}\right.$ and H-6'), $9.30(1 \mathrm{H}, \mathrm{t}, J=5.7 \mathrm{~Hz}, \mathrm{NH}), 11.63(1 \mathrm{H}, \mathrm{br} \mathrm{s}, \mathrm{NH}), 13.72$ $(1 \mathrm{H}, \mathrm{s}, \mathrm{COOH})$.

\section{Western blot analysis}

Equal amounts of protein $(50 \mu \mathrm{g})$ in each lysate sample were separated by $10 \%$ sodium dodecyl sulfate (SDS)-polyacrylamide gel. Proteins were then electroblotted on nitrocellulose membranes and the blot was probed with a primary antibody followed by a secondary antibody (rabbit antiPARP, goat anti- $\beta$-actin) conjugated to horseradish peroxidase.

\section{(E)-2-(dimethylamino)-4-(2-(dimethylamino)prop-1-enyl)-8-methyl-6H-pyrimido[1,2-} a][1,3,5]triazin-6-one (14).

Appropriate guanidine and excess equivalent of DMA-DMA (with/without toluene) were refluxed under nitrogen atmosphere. The reaction was monitored using TLC. The solvent was evaporated to dryness on rotary evaporator, purified using column chromatography and finally recrystallized using suitable solvent.

Yield: 73\%; physical appearance: orange; mp 212-213 ${ }^{\circ} \mathrm{C}$ (MeOH:AcOEt); MS (ESI) m/z: 289 $\left(\mathrm{MH}^{+}\right)$; Anal. calc. for $\mathrm{C}_{14} \mathrm{H}_{20} \mathrm{~N}_{6} \mathrm{O}: \mathrm{C}, 58.31 ; \mathrm{H}, 6.99 ; \mathrm{N}, 29.15$; found: 58.54; H, 7.17; N, 28.89 . 
${ }^{1} \mathrm{H}$ NMR (300 MHz, Me 2 SO-d $)$ : $\delta 2.06$ (3H, s, 9-Me), $2.64(3 \mathrm{H}, \mathrm{s}, 4-\mathrm{Me}), 3.05\left(6 \mathrm{H}, \mathrm{s},\left(\mathrm{N}(\mathrm{Me})_{2}\right)\right.$, $3.05\left(6 \mathrm{H}, \mathrm{s},\left(\mathrm{N}(\mathrm{Me})_{2}\right), 3.10\left(6 \mathrm{H}, \mathrm{s},(\mathrm{NMe})_{2}\right), 5.63(1 \mathrm{H}, \mathrm{s}, 8-\mathrm{CH}), 6.13(1 \mathrm{H}, \mathrm{s},=\mathrm{CH}-\mathrm{N}) ;{ }^{13} \mathrm{C} \mathrm{NMR}\right.$ (75 MHz, Me $\left.\mathrm{Me}_{2} \mathrm{SO} d_{6}\right): 18.2$ (4-Me), $23.6(9-\mathrm{Me}), 36.2\left(\mathrm{~N}(\mathrm{Me})_{2}\right), 36.4\left(\mathrm{~N}(\mathrm{Me})_{2}\right), 90.9$ (=CH-N), 101.1 (C-8), 154.7, 157.5, 158.4 (C-5), 157.5, 158.4, 161.3, 164.9, 166.1.

(E)-4-(2-(dimethylamino)prop-1-enyl)-8-methyl-2-morpholino-6H-pyrimido[1,2-a]

[1,3,5]triazin-6-one (14j). Yield: 69\%; physical appearance: yellow; $\mathrm{mp}$ 217-218 $\mathrm{C}$ (MeOH:AcOEt); MS (ESI) m/z: $331\left(\mathrm{MH}^{+}\right)$; Anal. calc. for $\mathrm{C}_{16} \mathrm{H}_{22} \mathrm{~N}_{6} \mathrm{O}_{2}: \mathrm{C}, 58.17 ; \mathrm{H}, 6.71 ; \mathrm{N}$, 25.44; ${ }^{1} \mathrm{H}$ NMR (300 MHz, Me $\left.2 \mathrm{SO}-d_{6}\right): \delta 2.06$ (3H, s , 9-Me), 2.61 (3H, s, 4-Me), $3.11(6 \mathrm{H}, \mathrm{s}$, $\left(\mathrm{N}(\mathrm{Me})_{2}\right), 3.65\left(4 \mathrm{H}, \mathrm{m},\left(\mathrm{CH}_{2}\right)_{2}, 3.72\left(4 \mathrm{H}, \mathrm{m},\left(\mathrm{CH}_{2}\right)_{2}\right), 5.67(1 \mathrm{H}, \mathrm{s}, 8-\mathrm{CH}), 6.17(1 \mathrm{H}, \mathrm{s},=\mathrm{CH}-\mathrm{N})\right.$;

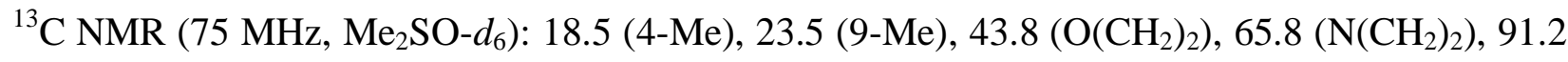
(=CH-N), 101.5 (C-8), 154.8, 157.6, 158.0 (C-5), 161.2, 165.4, 165.9; IR (KBr); v 3352 br., 1681 $\mathrm{C}=\mathrm{O}, 1616,1565,1171,979$.

\section{Acknowledgements}

This work is supported by the National Medical Research Council, Singapore (NMRC/NIG/0020/2008) and the National University of Singapore (R-148-050-091-101/133 and R-148-000-069-112). The authors thank Koh Lip Lin, Tan Geok Kheng, Woo Su Fen for the Xray crystallography study and Ms Tan Beejen for assisting in western blot analysis of compound 4 e.

Notes and references 
1. a) K. Arya and A. Dandia, Bioorg. Med. Chem. Lett., 2007, 17, 3298; b) D. Moreau, C. Jacquot, P. Tsita, I. Chinou, C. Tomasoni, M. Juge, E. A. Vyza, L. Martignat, A. Pineau, and C. Roussakis, Int. J. Cancer 2008, 123, 2676; c) N. Galili and A. Raza, Expert Opin. Pharmacother. 2010, 11, 1889; d) M. Ono, N. Kawahara, D. Goto, Y. Wakabayashi, S. Ushira, S. Yoshida, H. Izumi, M. Kuwano and Y. Sato, Cancer Res., 1996, 56, 1512; e) S. Nozaki, M. Maeda, H. Truda, and G. W. Sledze, Breast Cancer Res. Treat. 2004, 83, 195.

2. A.V. Dolzhenko, M. C. Foo, B. J. Tan, A. V. Dolzhenko, G. N. C. Chiu and W. K. Chui Heterocycles, 2009, 78, 1761.

3. A.V. Dolzhenko and W. K. Chui, J. Heterocycl. Chem., 2006, 43, 95.

4. A.V. Dolzhenko, A.V. Dolzhenko and W. K. Chui Heterocycles, 2008, 75, 1575.

5. Z. Nie, C. Perretta, P. Erickson, S. Margosiak, R. Almassy, J. Lu, A. Averill, K. M. Yager and S. Chu, Bioorg. Med. Chem. Lett., 2007, 17, 4191.

6. A. Ghaib, S. Menager, P. Verite and O. Lafont, Farmaco, 2002, 57, 109; b) I. T. Kay, Ger. Offen. DE 2452893, 1975.

7. D. W. Fry, P. J Harvey, P. R. Keller, W.L Elliott, M. Meade, E. Trachet, M. Albassam, X. Zheng, W. R. Leopold, N. K. Pryer and P. L. Toogood, Mol. Cancer. Ther., 2004, 3, 1427.

8. E. Bacque, M. Brollo, A. Clauss, Y. El Ahmad, B. Filoche-Romme, F. Halley, K. A. Karlsson, G. Marciniak, B. Ronan, L. Schio, B. Vivet, F. Viviani and A. Zimmermann, PCT Int. Appl. WO 001113 A2, 2011, 128pp.

9. M. A. Waly and M. I. Abou Dobara, Pol. J. Chem., 2009, 83, 1601. 
10. L. Lucry, F. Enoma, F. Estour, H. Oulyadi, S. Menager and O. Lafont, J. Heterocyclic Chem., 2002, 39, 663.

11. A. Lochead, M. Saady, and P.Yaiche, Pat. WO 2138488, 2009 (Chem. Abstr., 152, 119689).

12. For recent review on pyrimido[1,2-a][1,3,5]triazines, see: A.V. Dolzhenko Heterocycles, $2011, \mathbf{8 3}, 1489$.

13. a) E. Ziegler and E. Noelken, Montsh. Chem., 1961, 92, 1184; b) K. Hoegerle, H. Brechbuehler. Ger. Offen. DE 2450119, 1975, 17 pp; c) Y. A. E. Issac, Bull. Chem. Soc. Japan, 1999, 72, 503; d) Y. Singh and R. H. Prager, Aust. J. Chem., 1992, 45, 1825.

14. a) R. S. Hosmane and N. J. Leonard, J. Org. Chem., 1981, 46, 1457; b) Y. S. Agasimundin, F. T. Oakes and N. J. Leonard, J. Org. Chem., 1985, 50, 2474; c) I. T. Kay. Ger. Offen. 2452893, 1975; Chem. Abstr. 83, 97363 (1975); d) M. G. Karmouta, O. Lafont, C. Combet-Farnoux and M. Miocque, CR Acad. Sci. II C: Sci. Chim., 1977, 285, 25; e) M. G. Karmouta, O. Lafont, C. Combet-Farnoux, M. Miocque; M.C. Rigothier, B. Louchon and P. Gayral, Eur. J. Med. Chem.-Chim. Ther., 1980, 15(4), 341; f) L. Lucry, F. Enoma, F. Estour, H. Oulyadi, S. Menager and O. Lafont, J. Heterocyclic Chem., 2002, 39, 663; g) A. Kamal and P. B. Sattur, Synthesis, 1985, 9, 892; h) S. Kumar and N. J. Leonard, J. Org. Chem., 1988, 53, 3959; i) S. Nagai, T. Ueda, A. Nagatsu, K. Nakaoka, N. Murakami, J. Sakakibara, M. Fujita and Y. Hotta, J. Heterocyclic Chem., 1 998, 35, 329; j) C. V. Greco and K. J. Gala, J. Chem. Soc., Perkin Trans.1, 1981, 2, 331; k) M. R. Mahmoud, M. S. Abd-El-Halim, A. E. F. Ebrahim and A. M. Radwan, Indian J. Chem., Sec. B, 1996, 35B, 915; 1) R. Richter and H. Ulrich, Chem. Ber., 1970, 103, 3525; b) M. S. Amine, Egypt. J. Chem., 1998, 41, 267; m) M. Sawada, Y. Furukawa, Y. Takai and T. 
Hanafusa, Heterocycles, 1984, 22 (3), 501; n) P. Camus, M. F. Lhomme and J. Lhomme, Tetrahedron Lett., 1989, 30(4) 467; o) J. Boedeker, P. Koeckritz and K. Courault, Z. Chem., 1979, 19(2), 59; p) F. Ishikawa, A. Kosasayama, S. Nakamura and T. Konno, Chem. Pharm. Bull., 1978, 26, 3658.

15. A.V. Dolzhenko, N. Sachdeva, G. K. Tan, L. L. Koh and W. K. Chui, Acta Crystallogr. E 2009, E65, o684.

16. F. H. S Curd, W. Graham and F. L. Rose, J. Chem. Soc., 1948, 549.

17. a) for compound 6a: Sachdeva, N.; Dolzhenko, A.V.; Tan, G. K.; Koh, L. L.; Chui, W. K. Acta Crystallogr. E 2010, E66, o2050; b) for compound 4i and 10: Crystallographic data have been deposited with the Cambridge Crystallographic Data Centre (deposition number CCDC 791289 and CCDC 838638) as supplementary publication. Copies of the data can be obtained free of charge on application to CCDC 12 Union Road, Cambridge CB21 EZ, UK (Fax: (+44)1223 336-033; email: data_request@ccdc.cam.ac.uk).

18. M. J. Frisch, G. W. Trucks, H. B. Schlegel, G. E. Scuseria, M. A. Robb, J. R. Cheeseman, J. A. Montgomery, T. Vreven, K. N. Kudin, J.C. Burant, J. M. Millam, S. S. Iyengar, J. Tomasi, V. Barone, B. Mennucci, M. Cossi, G. Scalmani, N. Rega, G.A. Petersson, H. Nakatsuji, M. Hada, M. Ehara, K. Toyota, R. Fukuda, J. Hasegawa, M. Ishida, T. Nakajima, Y. Honda, O. Kitao, H. Nakai, M. Klene, X. Li, J.E. Knox, H.P. Hratchian, J. B. Cross, V. Bakken, C. Adamo, J. Jaramillo, R. Gomperts, R.E. Stratmann, O. Yazyev, A.J. Austin, R. Cammi, C. Pomelli, J.W. Ochterski, P. Y. Ayala, K. Morokuma, G. A. Voth, P. Salvador, J.J. Dannenberg, V.G. Zakrzewski, S. Dapprich, A.D. Daniels, M.C. Strain, O. Farkas, D.K. Malick, A.D. Rabuck, K. Raghavachari, J.B. Foresman, J.V. Ortiz, Q. Cui, A.G. Baboul, S. Clifford, J. Cioslowski, B.B. Stefanov, G. Liu, A. Liashenko, P. 
Piskorz, I. Komaromi, R.L. Martin, D.J. Fox, T. Keith, M. A. Al-Laham, C.Y. Peng, A. Nanayakkara, M. Challacombe, P.M. W. Gill, B. Johnson, W. Chen, M. W. Wong, C. Gonzalez and J. A. Pople; Gaussian 03, Revision C.02,Gaussian, Inc., Wallingford CT, 2004.

19. M. C. Alley, D. A. Scudiero, A. Monks, M. L. Hursey, M. J. Czerwinski, D. L. Fine, B. J. Abbott, J. G. Mayo, R. H. Shoemaker and M. R. Boyd, Cancer Res., 1988, 48, 589.

20. G.M. Sheldrick, SADABS, in: Program for Empirical Absorption Correction for Area Detector Data, University of Göttingen, Göttingen, Germany, 2000.

21. G.M. Sheldrick Acta Crystallogr. A 2008, A64, 112.

22. J. Sakai and M. Uohama, JP 97-232411, 1997.

23. K. Tetsuzo, C. Takuo, S. Takeshi and T. Hitoshi, Chem. Pharm. Bull., 1981, 29(3), 862.

24. N. Sachdeva, A. V. Dolzhenko and W. K. Chui, C. R. Chimie, 2011, 14, 580.

25. F. H. S. Curd, J. Chem. Soc., 1946, 362.

26. F. H. S. Curd, US Pat. 2422890, 1947.

27. F. Mitsuru, Y. Takatoshi, G. Motoo and H. Seigoro, Chem. Pharm. Bull., 1973, 21(12), 2594.

28. B. K. Paul, Indian J. Chem. B, 1976, 14B(11), 887.

29. a) M. R. Ganjali, Anal. Sci., 2004, 20(10), 1427; b) P. Franz, J. Prakt. Chem, 1909, 77, 533; c) A. Mario, O. Daniel, W. Donald, Leslie M. and J.W. McCall, J. Med. Chem., 1983, 26, 1258. 